This is the post-peer reviewed final draft version of the following article: Heeks, R. \& Nicholson, B. "Software export success factors and strategies in "follower" nations", Competition \& Change, 8(3), 267-303, 2004, which has been published in final form at: http://www.tandfonline.com/doi/abs/10.1080/1024529042000301962

\title{
SOFTWARE EXPORT SUCCESS FACTORS AND STRATEGIES IN "FOLLOWER" NATIONS
}

\author{
RICHARD HEEKS $^{*}, 1$ and BRIAN NICHOLSON ${ }^{\dagger, 2}$
}

*Institute for Development Policy and Management and ${ }^{\dagger}$ School of Accounting and Finance, University of Manchester, Precinct Centre, Manchester, M13 9GH, UK

Many countries worldwide are becoming active or interested in software exports. This paper initially analyses the software export experiences of India, Ireland and Israel; the three largest software "followers" (those which developed a software industry after the 1970s). It develops a new "Software Export Success Model" on the basis of that analysis. This model, having been developed as a descriptive/analytical framework, is then applied in a number of ways. First, as a comparative framework, helping to identify current strengths and weaknesses of two "second-tier" followers Russia and China - as compared particularly to India. Second, as a predictive foundation for understanding likely sectoral trajectories within these second-tier nations. Finally, as a prescriptive foundation from which guidance can be derived on the strategies and interventions that these countries may need to adopt for software export growth. As well as demonstrating the value of this new framework for conceptual analysis, then, this paper also shows how it can have practical value to policy-makers, industry association representatives, consultants and others involved with software sector strategy. Although beyond the scope of this paper, it appears that the model will also serve as a framework for equivalent analysis and guidance for the many other follower nations who have recently entered into software exports.

\footnotetext{
${ }^{1}$ Corresponding author. Email: richard.heeks@man.ac.uk

${ }^{2}$ Email: brian.nicholson@man.ac.uk
} 
Keywords: Software industry, Export strategy, Competitive advantage, Success factors, India, Ireland, Israel, Russia, China

\section{INTRODUCTION}

The software sector is of growing importance globally with some US $\$ 400 \mathrm{bn}$-worth of software packages and services being produced in 2003 (Minton, 2003). The major software industries of the world are - not coincidentally - located in the world's richest economies; countries that have been building those industries since the earliest days of computing, with particular growth achieved since the unbundling of software from hardware in the late 1960s.

These countries - such as the US, Japan, UK, France, Germany, Italy - therefore had significant software industries from the 1970s onwards. Their industries have been much commented-upon and researched (e.g. Mowery, 1996; Campbell-Kelly, 2003), and they are not the focus of this paper. Instead, here, we investigate those countries which are latecomers to software: so-called "follower" nations that, after the 1970s, have found - or are trying to find - a place in an already competitive industry.

In terms of software industry focus, two dimensions can be identified (Heeks, 1999b):

- Market served: sales to export and/or domestic markets.

- Output type: sales of software products and/or services.

In this paper, we will look at both products and services, but - while we do discuss export - domestic linkages - we will focus on software exports. In part, we do this because success in exports is a stronger mark of competitiveness than success in the domestic market (Porter, 1990).

In addition, the benefits of software exporting appear greater than those from domestic orientation for follower nations. Barriers to entry into exports are greater than for entry into domestic sales. Software exports can also exacerbate inequalities, since they are often virtual enclave activities with relatively few trickle-down benefits to the poor ${ }^{3}$. However, the general developmental rewards of software exports are

\footnotetext{
${ }^{3}$ Or, more accurately, few benefits that have been charted, since linkages between IT exports and local poverty alleviation remain largely unresearched.
} 
greater, in terms of income/productivity per head, profits, foreign exchange earnings, and the infusions of knowledge that can accompany international operations (Correa, 1996; Arora and Athreye, 2002; Heeks and Grundey, 2004).

We also take an export focus because of the considerable interest in software exports that has arisen among most developing and transitional countries. This interest has been piqued by the perceived export success of the "first-tier" followers, a success that other nations hope to repeat.

Our purpose, then, is to focus on those first-tier follower countries that successfully built export-oriented software industries during the 1990s, to learn from their experiences, and to then examine the status of "second-tier" followers in the light of those experiences. In the next section, we start by identifying the first-tier followers India, Ireland and Israel - and by providing a brief overview of software sector development in each of those countries. We then adopt an exploratory inductive approach of content analysis that develops a new categorised model of factors which have been associated with software growth in each of these countries - the Software Export Success Model - and describe findings on its factors. Next, we use the model as a comparative framework to analyse data on the current situation in two second-tier followers: Russia and China. This provides us, finally, with the basis for a predictive and prescriptive analysis of likely trajectories and strategies for the software sectors in these two countries; an analytical approach that can be extended to many other follower nations.

The data reported in this paper is drawn from three main sources. First, secondary sources including individual country case studies and comparative analyses. Second, primary research on software industries in follower nations; principally India. This has involved 176 semi-structured interviews of one-two hours' duration supplemented by observation and document analysis during the period 1988-2003. Interviews were undertaken with software firm managers, programmers, government officials and sector analysts. Third, primary research in the UK, US and Norway over the same time period involving 56 interviews with managers in firms involved as either clients of, or investors in, software companies in follower nations. ${ }^{4}$

\footnotetext{
${ }^{4}$ Details of follower nation interviews and research project periods are: 1988-89 (India - 65 software firm managers, 23 programmers, 30 government officials, 17 sector analysts, 3 association representatives);
} 


\section{FIRST-TIER SOFTWARE FOLLOWERS: THE "3Is"}

In common with a number of other authors (e.g. Arora et al., 2001b; Carmel, 2003a), we have divided off the "3Is" - India, Ireland and Israel - as a separate tier within the general mass of follower nations. What justifies this separation, and the assumption that the 3Is are worthy of examination in relation to software export "success"?

In simple terms, these three can be seen as the most successful of the export followers because they have the largest software exports of the countries which only began exporting after the 1970s: see Table I. However, we can also identify some other characteristics that make the 3Is unique among follower nations:

- Longevity: these countries have first-mover status among follower nations, with all three beginning recognisable software exports before the 1990s.

- Global significance: together in 2003, the 3Is' exports alone (not counting their domestic-oriented software production/sales) accounted for more than $7 \%$ of global software production. Individually, each has maintained a share of at least $0.5 \%$ of global production for more than seven years, and we can use this as the specific defining characteristic of first-tier followers.

- National significance: in 2003, software exports contributed $1.5 \%$ or more of GDP and more than $5 \%$ of total goods and services exports in each of the 3Is (see Table II). The former figure is greater than in the G7 countries, where total software production (i.e. for domestic and export markets) averages less than $1.5 \%$ of GDP (Arora and Gambardella, 2004).

1995-99 (India - 10 software firm managers, 5 programmers); 1998-2000 (India - 10 software firm managers, 4 programmers); 2002 (India - 4 firm managers, 1 government official; Russia - 1 consortium representative; China -1 association representative); 2003 (India -2 software firm managers). Details of client/investor nation interviews are: 1988-89 (UK - 7 managers, 3 association representatives); 1995-99 (UK - 15 managers); 1998-2000 (UK - 7 managers); 2000-2003 (UK - 13 client firm managers, 2 consultants; US - 5 client firm managers, 3 consultants; Norway - 1 client firm manager). Other findings from this primary research are reported elsewhere, e.g. Heeks (1996), Heeks et al. (2001), Nicholson and Sahay (2001), Lai et al. (2003) and Sahay et al. (2003). 
TABLE I Software Exports from the 3Is.

\begin{tabular}{cccc}
\hline Year & $\begin{array}{c}\text { India } \\
(\mathrm{US} \$ \mathrm{~m})^{5}\end{array}$ & $\begin{array}{c}\text { Ireland } \\
(\mathrm{US} \$ \mathrm{~m})^{6}\end{array}$ & $\begin{array}{c}\text { Israel } \\
(\mathrm{US} \$ \mathrm{~m})\end{array}$ \\
\hline 2003 & 8800 & 17700 & 2680 \\
2002 & 7550 & 16000 & 2550 \\
2001 & 6200 & 15100 & 2650 \\
2000 & 5300 & 10500 & 2600 \\
1999 & 3600 & 8050 & 2000 \\
1998 & 2180 & 7230 & 1500 \\
1997 & 1650 & 6710 & 1000 \\
1996 & 1000 & & 600 \\
1995 & 670 & 4410 & 300 \\
1994 & 480 & & 220 \\
1993 & 310 & 2890 & \\
1992 & 220 & & \\
1991 & 170 & 2520 & 100 \\
\hline
\end{tabular}

Source: India (interviews, Dataquest (India) surveys, Dept. of Electronics/Dept. of IT annual surveys); Ireland (NSD, 2004); Israel (Khavul, 2003; IEICI, 2004).

\footnotetext{
${ }^{5}$ Indian figures are for the financial year to end March (e.g.. 2003 figure is for period April 2003 to March 2004). These figures represent gross earnings. Calculations based on earlier interviews suggest net earnings for India to be about $40 \%$ of gross because of outflows of foreign exchange from India to pay for: travel and living allowances of Indian software workers who undertake their contracts overseas, marketing, multinational profit repatriation, importation of hardware and software, etc. (Heeks, 1999a). This estimate is not far off the more recent calculation by McKinsey which estimated that $67 \%$ of all offshore IT outsourcing expenditure from US firms is directly recaptured by the US economy (Olive, 2003).

${ }^{6}$ At least according to some figures (e.g. Woods, 2004), the quoted levels of software export would mean Ireland is a larger software exporter than the US (where, for example, official forms recorded exports of US\$13bn in 2002). Yet the Irish software sector employs around 30,000 whereas the US software sector employs more than one million. Even allowing for a lot of Irish talent, luck and hard work, these figures just do not add up. Their explanation - both US and other leading economy under-reporting and Irish over-reporting - is transfer pricing by software multinationals booking exports in Ireland (which has low corporate tax rates) for products that were developed in the US and other G7 nations. The true level of Irish software exports is hard to estimate. One approach would be to extrapolate figures from the indigenously-owned part of the industry (which is assumed not to transfer price). Assuming equivalent per employee export rates between the domestic- and foreign-owned parts (a questionable assumption, but better than ignoring transfer pricing), this would suggest exports in 2003 around the US $\$ 3 \mathrm{bn}$ mark. This would amend the figures in Table II to $2.01 \%$ of GDP and $2.5 \%$ of exports. Other sources have halved the headline figure; for example, citing true exports in 1999 as c.US\$4bn (Kelly, 2000; OECD, 2000).
} 
TABLE II 3I Software Exports as a Proportion of GDP and Exports.

\begin{tabular}{lccc}
\hline Software Exports & India & Ireland & Israel \\
\hline $\begin{array}{l}\text { Software exports as \% of GDP } \\
(2003)\end{array}$ & $1.47 \%$ & $11.9 \%$ & $2.58 \%$ \\
$\begin{array}{l}\text { Software exports as \% of goods \& } \\
\text { services exports (2003) }\end{array}$ & $10.1 \%$ & $13.2 \%$ & $6.38 \%$ \\
\hline
\end{tabular}

Source: World Bank world development indicators; World Trade Organisation world trade indicators.

Detailed analysis of the factors associated with this software export success will be given in the next section. Here, we present a brief historical and statistical picture of each country's software export sector.

\section{India}

India exported its first software services and products in the mid-1970s. However, it was not until the 1980s that vigorous and sustained growth began, as multinational corporations (MNCs) like Texas Instruments started to take a serious interest in India as a centre for software production (and as a market for products).

There have been continuous exports of software products since the early 1980s. These include enterprise systems, design software, and database management tools. However, products have never formed more than 5\% of total exports and, in 2003/4, they made up $2.7 \%$ of the total (Heeks, 1999a; Ahmad, 2004). Indian software exports have been, and remain, dominated by services.

Within the overall segment of software services exports, though, trends of change are detectable. Indian firms began with a strong emphasis on "bodyshopping": the transportation of software staff to work overseas at the client's site. In the late 1980s, around $75 \%$ of export earnings came from bodyshopping. By 2000 , this had dropped to nearer $60 \%$ (Dataquest, 2001) and by 2003 it was closer to 50\% (McNurlin, 2003; Nasscom, 2004), indicating a slow but steady trend towards offshore working. 
This has been paralleled by a second trend: that of moving from supply of individual programmers to complete turnkey programming project services. As with offshore working, we have seen in our fieldwork over the years that the trend of change has been greater within individual client — vendor relationships than in the industry overall. Nor has the industry overall diversified much from its main market: the US. Figures from the early 1990s up to 2003/4 consistently show around two-thirds of software exports going to the US, one-fifth going to Europe (mainly the UK, Germany and France), and about 10\% going to other English-speaking OECD nations (e.g. Australia, Canada) (Heeks, 1996; Nasscom, 2004).

India's US $\$ 8.8 \mathrm{bn}$-worth of software exports in 2003/4 reflect average annual growth of more than $35 \%$ over two decades. The result is that - for many years - India has been the developing world's software leader, claimed to take more than $80 \%$ of the global software outsourcing market, and to have provided software services for more than half of the Fortune 500 (Qu and Brocklehurst, 2003; Sahay et al., 2003). Such claims are much-touted but hard to verify, as are other statistics on Indian (and other country) software. The total number of software firms (domestic and export) could be as high as 6,000 though probably less than 1,000 of these are actively engaged in exports (Economic Daily, 2002; Kublanov and Satyaprasad, 2004). Software employment figures also vary, with estimates of those working in software exports ranging from 100,000 (KPMG/Nasscom, 2004) to 450,000 (Kublanov and Satyaprasad). ${ }^{7}$

Predictions of US\$50bn-worth of exports by 2008 (Nasscom/McKinsey, 1999) seem over-optimistic. Nevertheless, there are expanding opportunities in e-commerce, $\mathrm{m}$ commerce and legacy-to-Web services amongst others (Moitra, 2001). There is currently no reason to expect anything other than continued double-digit growth.

\footnotetext{
${ }^{7}$ Interview data suggests variation depends partly on whether or not figures include software activity in non-software firms; partly on whether or not they include non-software staff working in software firms.
} 


\section{Ireland}

Ireland's software activity can be charted back to the early 1970 s and three things: Irish entry into the European Economic Community, the deliberate efforts of its Industrial Development Authority to attract high-tech multinational investment via financial incentives ("such as employment, training, capital and R\&D grants"), and heavy investment in education and telecommunications (O'Riain, 1997; Coe, 1999). This particularly began to bear fruit in the 1980s (services were targeted for investment from 1981 and the software industry was officially recognised in 1989) and 1990s, as Ireland's IT reputation spread and as European market unification made Ireland an attractive European production base (Gallen, 2001).

A major initial area of software export activity lay across the boundary of services and products. Software multinationals, typically from the US, came to Ireland to set up local subsidiaries. These local ventures did not write the main original code but undertook localisation (such as addition of interfaces and manuals in UK English and other European languages) and then locally produced and distributed the shrinkwrapped packages.

This work remains the dominant component of the Irish software industry, which exports roughly half of its software to the UK and around $70 \%$ to the EU overall (Arora et al., 2001b; Reed and Kelly, 2002). However, during the 1990s there were concerted efforts to diversify the nature of the industry. The multinationals were encouraged to move up the value chain and to outsource more highly-skilled work to their Irish subsidiaries. Alongside this, an indigenously-owned Irish software industry grew up (Grimes, 2003). This part of the industry is often portrayed as productfocused; working on niche areas such programming languages and tools, and products for specific sectors such as financial services (Cochran, 2001). However, at least half of export earnings appear to come from software services where the emphasis has been on Internet and multimedia consulting, with a focus on turnkey projects rather than bodyshopping (EI, 1997; Loane, 2003).

As noted above, the headline figures cited for Irish software exports are of limited use given that, overall, they do not properly represent local value-added in software but 
instead incorporate accounting practices by multinationals shaped by national and regional fiscal and legal regimes. A slightly more accurate - albeit partial - picture may be obtained from the Irish-owned segment of the industry, which grew from US\$180m exports in 1993 to US\$1.36bn in 2003: an average annual rate of more than $22 \%$ (calculated from NSD, 2004). As with Israeli and Indian software exports, this overall picture masks faster growth up to 2000 (more than $30 \%$ per annum) and slower growth thereafter ( $8 \%$ per annum up to 2003 , including a fall of $16 \%$ from 2002 to 2003).

By 2004, there were roughly 900 firms in the software industry overall (not just exports) of which 140 were foreign-owned (NSD, 2004). Some 24,000 were employed in the industry, down from a peak of roughly 31,500 in 2001. Despite these losses, exports overall continue to show double-digit growth thanks to the strength of the overseas-owned segment which accounts for roughly $55 \%$ of employment.

\section{Israel}

The very early roots of Israel's software success lie, as they do for India, in the postindependence, government-funded drive to increase technical expertise. A technically-proficient cadre trained by the military in the 1950s found themselves in key positions from the 1960s onwards (Ariav and Goodman, 1994). This cadre formed a network that spanned the military, the government and the private sector. As computer hardware and then software became commoditised, an opportunity presented itself. The cadre was able to see opportunities for software as a private sector enterprise (Teubal et al., 2000).

Beginning slowly in the late 1970s and early 1980s, this trend of software development work really took off during the 1990s with the arrival of investment funds from overseas. Israel's main strength has been the export of niche market software products. These particularly include Internet-related products such as communications utilities; enterprise software; and information security, including anti-virus tools (de Fontenay and Carmel, 2003). Even these categories are broad, and Israeli firms have tended to concentrate on small niches within any given category. 
Newer but lesser product categories include application generators, database management tools and educational software.

The result was rapid expansion of software exports during the 1990s. Average annual growth rates were more than $40 \%$, culminating in US\$2.6bn-worth of exports in 2000 of which around $40 \%$ went to the US and another $40 \%$ to the EU (IEICI, 2004). As discussed below, though, growth then flattened, with exports roughly static from 2000-2003. In 2002, there were estimated to be around 400 firms in the Israeli software industry (Khavul, 2003). Government estimates put the number of IT staff in the industry at 13,000; other estimates cite a figure of 20-35,000 (ibid.; Sahay et al., 2003; IEICI, 2004). As in the past, the Israeli industry seems likely to mirror the global picture, with software exports picking up as and when global software sales rise.

\section{FACTORS IN SUCCESSFUL SOFTWARE-EXPORT FOLLOWERS}

How have these three follower nations been able to succeed in software exports? To try to answer this question, we undertook a "template analysis" of qualitative data on the 3Is drawn from our interviews plus available secondary sources (King, 1998). We began by first identifying those factors for which some causal link was made to software export growth in one or more of India, Ireland and Israel. At least thirty different potential factors were identified but, on analysis, we found that they could be categorised into five main headings:

- Demand: both global and local.

- National vision and strategy: the goal and the interventions to build software exports.

- International linkages: including reputational effects and trust.

- Software industry characteristics: including size, competition, clustering and collaboration.

- Supply factors and infrastructure: such as human capital, technology and finance. 
Appendix 1 summarises the main base of data for this analysis: categorisation of success factors from interview data plus selected secondary sources. ${ }^{8}$ In the remainder of this section, we will draw on this base to describe each of the five categories in greater detail, to help provide a greater understanding of factors that have helped contribute to the growth and development of software exports in India, Ireland and Israel.

\section{Demand}

In all three countries, the nature of demand has been fundamental. Given the definition of 3I success in terms of exports, global demand has been of primary importance. In the twenty or so years since these countries began exporting, the global software and services market has registered average growth of roughly $20 \%$, from around US\$10bn in 1983 (Heeks, 1996) to the US\$400bn in 2003 cited above. This rapid growth created a huge gap between demand for, and supply of, software labour with shortfalls in the early years of the $21^{\text {st }}$ century quoted in the hundreds of thousands for leading economies (KPMG/Nasscom, 2004). Running alongside the more general growth of IT outsourcing and growth of global sourcing of goods and services, this has created a strong pull into the software export market. It also - at least in the 1990s when few follower nations were active - was forgiving of delays, errors, learning curves, etc.

The importance of global demand was underlined during 2000-2003, when the world software market is estimated to have shrunk by up to 3\% per year (Kodituwakku, 2003). On the positive side, all three countries emerged in 2003 with exports higher than in 2000. India showed itself to be the most robust exporter. Annual growth rates may have halved but this still left them above $18 \%$, helped by the fact that outsourcing services to low-cost locations is a tactic used by Western clients in both expansionary and recessionary times. Even so, interviewees told us of programmers being returned to India from US and European locations as contracts were cancelled or postponed. Because of their greater product focus, Ireland and Israel suffered more. This was reflected in the employment and export data noted above and seen in

\footnotetext{
${ }^{8}$ Development of the model has also benefited from feedback during its use in teaching, in conference presentation (Heeks and Nicholson, 2002) and in field application (e.g. Nicholson and Sahay, 2003).
} 
the estimate that some 140 software firms failed in Israel during 2000-2002 (Khavul, 2003).

From some models - such as Porter's (1990) - one might expect to see domestic demand as a key component of long-term industrial competitiveness. Interview and secondary data suggests that domestic demand has been important in all three countries but partly in relation to its weakness rather than strength. Indian software entrepreneurs stated that they had moved into exports because of the small size and low profitability of the domestic market. Similar findings are reported from Ireland and Israel (Bell, 1997; de Fontenay and Carmel, 2003). In India's case, domestic market limitations arise - despite its large population - from low disposable incomes, low investment, and high piracy rates. Ireland and Israel suffer less from these problems and more from simple lack of population: c. $4 \mathrm{~m}$ and c. $6 \mathrm{~m}$ respectively. The result, as summarised in Table III, is that the overall software sector in all 3Is is strongly export-oriented. ${ }^{9}$

TABLE III Balance of Export- and Domestic-Oriented Revenue in 3Is.

\begin{tabular}{lcccc}
\hline & India & Ireland & $\begin{array}{c}\text { Ireland (local- } \\
\text { owned only) }\end{array}$ & Israel \\
\hline $\begin{array}{l}\text { 2003 domestic-oriented } \\
\text { revenue }\end{array}$ & US\$2.0bn & US\$0.7bn & US\$0.33bn & US\$1.0bn \\
$\begin{array}{l}2003 \text { total software } \\
\text { revenue }\end{array}$ & US\$10.8bn & US\$18.4bn & US\$1.69bn & US\$3.8bn \\
$\begin{array}{l}\text { Export proportion of } \\
\text { total revenue }\end{array}$ & $81 \%$ & $96 \%$ & $80 \%$ & $73 \%$ \\
\hline
\end{tabular}

Source: as for Table I.

This is not to deny any connection between domestic demand and exports.

Demanding local consumers - often in the form of local multinational subsidiaries in other industries, such as financial services - have been used as a conduit from the

\footnotetext{
${ }^{9}$ In general, that export orientation has strengthened over time. In 1991, for example, the equivalent figures for exports as a proportion of total software revenue were: India c.60\%; Ireland overall: 93\%; Ireland local-owned only: 41\%; Israel: c. 20\% (Heeks, 1996; Arora and Gambardella, 2004; NSD, 2004).
} 
domestic to the export market by software product producers in all three countries (Arora et al., 2001b; Tessler et al., 2003). Nevertheless all three countries - from Israel least to India most - retain features of an enclave economy within software exports, with international linkages in many cases stronger than local ones.

\section{National Vision and Strategy}

All three first-tier software exporters have had a national strategy to promote their software industries generally and software exports particularly. The presence of a national strategy for software exports is therefore recognised as a vital part of software export success (Balasubramanyam and Balasubramanyam, 1997; Watson and Myers, 2001). Indeed, it goes beyond this: central to the development of software in each country has been a vision of what software could achieve for the country; a vision shared by a relatively small but committed group of government officials and private entrepreneurs (Heeks, 1996; O'Riain, 2000; Teubal, 2001). Such visions first emerged in the 1970s, were sustained through lean early years in the 1980s, and then truly came to fruition in the 1990 s.

This has typically required institutional support within government, such as that found in Ireland's Industrial Development Authority and its National Software Directorate, and in industry, such as India's National Association of Software and Services Companies (Nasscom). Just as important, it has required links between industry and government that, for example, help ensure new policy proposals are "enterprisefriendly" (Tessler et al., 2003).

The detail of strategies for achieving each vision has undoubtedly been somewhat iterative. That is, it did not cast the exact vision of market segments in stone a priori. Instead, given some starting point, strategy has flexibly reacted to what has worked (and what has not). In India, for instance, the capacity for such iteration and flexibility - found both within government and within the private sector - was identified from our interviews with policy-makers and company heads as a further fundamental contributor to software export development. 
We discuss later the overlaps in what the 3Is are doing (all export some software products; all export some software services). However, here we begin with the picture of differentiation. India is dominated by software services; Ireland is dominated by product-related services for multinationals; Israel is dominated by product exports. This differentiated branding is seen to have helped each to succeed as simultaneous first-moving followers into the global software market.

That, of course, has been their most important initial strategy: to be first with something new. But what succeeding strategy have they now been adopting to sustain market share given that they are no longer alone? This has been the key challenge for all three that has driven succeeding strategy: increasing competition from other software followers. Given their different market segments, though, and other differences, each country has followed a somewhat different strategic path.

India had a starting point of bodyshopping programming services and firms faced challenges of rising labour costs and brain drain of staff based onsite as well as competition from new entrants. The key succeeding strategy in the Indian software industry has therefore been that of offshore management: undertaking contract work in India rather than at the client site and developing the necessary project management skills to enable this. This is reflected, for example, in figures on the Capability Maturity Model (CMM): a certification scheme with various levels that verifies the quality of management of the software programming process. By 2004, of 80 companies worldwide certified to CMM level 5 (the highest level), 60 were Indian software firms (DoC, 2004), and there had been 330 reported CMM appraisals in India, a figure second only to the US and well above that for nations such as the UK or Germany (SEI, 2004).

Some care must be taken with the idea of the succeeding strategy. Interviews show that it has been particularly successful within individual client-developer relationships, where it has sometimes been accompanied by vertical market specialisation (i.e. a focus on Western clients in a particular sector such as financial services, banking, insurance or telecommunications). In the sector overall, though, there is still a lot of onsite work (bodyshopping) and one gets an image of a vacuum 
effect as if, for every large firm that moves from onsite to offshore working, five new small firms enter the industry via the low-barrier onsite model.

What Indian firms do not seem to have done in any major way, despite the cost and profit advantages this would bring, is move up the value chain to more highly-skilled software work, such as that involved with analysing client requirements or design program specifications (Arora and Gambardella, 2004). It is thus unclear what, if anything, might constitute India's "third wave" strategy after onsite then offshore. There are limited amounts of product development, research and development work, and other high-skill activity. However, at present, most time and attention seems to be focused on transferring the project management expertise, reputational effects and strong infrastructure into IT-enabled services - call centres, data entry, forms processing, accounting, etc. - at least at a sectoral level if not at an individual firm level (KPMG/Nasscom, 2004).

Ireland has faced challenges similar to those in India, such as rising labour costs (Irish GDP per capita now outstrips that of the UK) that have exacerbated fears about competition from other, cheaper locations and about "footloose" multinationals moving away to such locations. As described above, the response to the initial monoculture of localisation/customisation of foreign packages can be seen as one of embedding the software industry in two main ways. First, by trying to get the multinational subsidiaries to locate a broader and higher-skill range of their activities in Ireland; both India-style software outsourcing work and higher-end package management activities. Second, by nurturing an indigenous, Irish-owned software industry.

The results of this succeeding strategy have been mixed but there is evidence of multinationals diversifying into software services work (which now accounts for around one-third of their activity) or setting up new software-related activities, deepening their commitment "by means of expanding their business planning and customer management operations" in Ireland (Grimes, 2003:9). The picture for the locally-owned segment is also "half-full, half-empty" with strong early growth rates and a mix of product and service exports balanced against the post-2000 downturn which saw more than one-quarter of jobs lost in this part of the software industry. 
For Israel, already at the top of the software value chain, the main challenges have been obsolescence of current products or competition from other product firms. Its exporters' strategy has therefore been one of innovation and differentiation. It is continuing to produce new software products in existing market niches. At the same time, it is making new software products in new market niches in order to retain market share. This strategy has been supported by its development from a rather small and inward-looking military-trained cluster to a group with strong international linkages (Teubal, 2001). It is these linkages that we investigate next.

\section{International Linkages}

Export success entails making and sustaining linkages with markets and customers (and suppliers) overseas. All three countries have been strong in this. At the original and often continuing root of such linkages has been a national diaspora. For Ireland and Israel, flight from poverty and/or persecution settled large numbers overseas, particularly in the US, prior to the creation of the current nation states. More importantly, from the 1960s onwards, all three countries have been losing managers and other professionals to the lure of the green card: around $60 \%$ of the native-born US-based population from these countries are in management or the professions; roughly twice the US average (Kapur and McHale, 2002).

Often maligned as a costly "brain drain", this recent professional diaspora formed the basis for contacts and then contracts that set each country's software export operations in motion. Scratch beneath the surface of all early exports and you find a 3I expatriate who was central in persuading their US-based (or, less often, Europebased) employer to collaborate with a 3I supplier or set up a 3I base (Arora et al., 2001a; Carmel, 2003b). As emigration has continued (fostered by software exports in some cases), the potential for ever-more linkages and ever-more trade grows too.

These linkages have brought more than just trade contacts; they also provide market information and money. Saxenian's (2002) study, for example, found that half of Silicon Valley's India-born population had business contacts in India while one- 
quarter had invested in an Indian start-up. The value of the diaspora - their knowledge, skills, and social and financial capital - has been enhanced through reverse migration (Kapur and McHale, 2002). Returnees have come home to invest in software start-ups in all three countries, especially since the mid-1990s. In Ireland, for example, one survey found that $74 \%$ of locally-owned software firms had at least one founder who had previously worked abroad (Arora and Gambardella, 2004).

Although the diaspora has been vital, more standard marketing operations have also been used to build export trade. Governments have helped by formulating high-level trade links, by providing market information, by organising and subsidising attendance at overseas trade fairs and exhibitions, and by supporting the formation of trade/industry associations like India's Nasscom (Heeks, 1999b; Tessler et al., 2003). 3I companies have helped themselves by setting up subsidiaries in overseas markets, enabling them to get closer to customers and/or partners. For example, the Irish government has set aside specific financial support for overseas expansion by local software firms, leading 70 to have subsidiaries in the US alone (Cochran, 2001). Likewise, around half of Israel's high-tech firms have offices abroad, particularly in the US (Khavul, 2003).

Getting close to the customer is also part of building trust; a factor that underlies all software trade (Sabherwal, 1999; Sahay et al., 2003). All imports involve risk for clients, especially the outsourcing of services to remote locations. Without some degree of trust, no trade will take place. Our interview data suggests that good marketing and diasporan contacts get over the initial trust barriers. They continue to be surmounted by fulfilment: the ability of 3I software firms to deliver sufficiently high-quality software outputs close enough to time and budget and requirements in order to sustain trust. This has given each 3I country a reputation and track record that reduces perceived risk and enhances trust (and that also raises barriers to entry of other follower nations).

The building of trust has particularly been possible through the creation of close, expanding client-developer relationships (Heeks et al., 2001). Many or most of the significant players in all 3I software exports have been involved in relationships with single, large multinational clients. Typically, these clients have invested in a local 
subsidiary or joint venture. ${ }^{10}$ By thus internalising market transaction costs, they have saved money and also built the trust that has enabled expansion of export operations.

All 3I governments have encouraged such linkages by offering tax breaks and other financial and non-financial incentives to multinational investors in software exports, and by removing red tape for business operations (Tessler et al., 2003). The result, for example in India, has been the presence of software subsidiaries for almost all major IT firms, and for many other leading multinationals.

A number of other 3I actions can also best be understood in terms of trust. The enthusiasm in India and Ireland for process/quality certification such as ISO9000 or Capability Maturity Model is one. There are few signs that certification actually improves a software firm's capacity to deliver a product that meets the clients' needs (Weston, 2004). This may explain the relatively few firms in product-focused Israel that have undertaken certification (SEI, 2004). But what it does do is send a powerful signal to distant clients that firms are like their clients, will work according to their norms, and will submit themselves to external, global standards. Certification is thus seen as an integral part of trust and "comfort" for clients considering software services outsourcing (Weston, 2004).

Likewise, action on software piracy and copyright - although forced on 3I countries at the political level - can also be read as a trust-building measure, assuring clients that the 3I nations are trustworthy in terms of their intentions. India, for example, has passed increasingly strong anti-piracy/copyright legislation for software in 1984, 1994 and 2000. For Ireland, with its software package production base, strong copyright laws were an essential starting point.

Lastly, the general political stability and reputation of a nation, or even its region, can be found to either build or undermine trust in potential overseas clients and investors (Qu and Brocklehurst, 2003; Valimaki, 2004). The 3Is have suffered some regional ups (such as the Northern Ireland Peace Accord) and downs (such as the tensions between India and Pakistan, and Israel and Palestine), with the latter potentially impacting investment (Khavul, 2003). Beyond these variations, though, interviews

\footnotetext{
${ }^{10}$ Although, in India, we also found examples of strong and sustained relationships between foreign multinationals and local software firms that did not involve equity investments.
} 
with clients and investors suggest that the enduring national image of stable democratic institutions has counted in the 3Is' favour.

\section{Software Industry Characteristics}

Given their different operations, the characteristics of each 3I software industry do differ. However, four characteristics stand out as common; albeit with some caveats. First is concentration; specifically the presence of a number of firms in each country that are large enough to build strong reputations or even brands, to withstand market fluctuations, and to achieve any scale economies that software development can offer. As seen above, the major part of Ireland's industry is formed by multinational subsidiaries. In Israel, four main firms have dominated the software industry, with average sales around ten times that of their nearest competitors (Teubal, 2001). In India, the top ten firms earn 57\% of software export revenues; sixteen are US\$100m exporters; and the largest - Tata Consultancy Services - exports more than US\$1bn per year (Ahmad, 2004).

The second characteristic is competition between firms. All three industries are dominated by privately-owned firms and barriers to entry and exit are relatively low. Beneath the largest players, then, are hundreds of medium-size (50-500 staff) firms competing relatively freely with each other. In theory, this should help to drive down costs and to stimulate innovation. This effect is perceivable in the product-led sector, as in Israel (de Fontenay and Carmel, 2003), but the impact of competition is less clear in services. The massive global gap between demand and supply for software labour has left many Indian and Irish firms involved with outsourcing feeling they are "pushing at an open door", and experiencing relatively weak inter-firm competitive pressures (Krishna et al., 2000). The result has been that many firms follow essentially imitative strategies rather than strategies of innovation or differentiation.

Third, there has been clustering. Most software export firms in the 3Is cluster around a few locations: Bangalore, Mumbai, Chennai, Delhi and Hyderabad in India; Dublin in Ireland; and Tel Aviv, Haifa and Jerusalem in Israel (Sahay et al., 2003). There is evidence of locational economies in the more efficient provision of physical 
infrastructure and labour/capital supply inputs to a cluster of software firms than to the same number of firms that are dispersed (de Fontenay and Carmel, 2003).

Governments have supported this by helping deliver infrastructure to the clusters. It has also been assumed that clusters enabled rapid interchange of information and knowledge, for example about best practices and about market opportunities. However, other than through the circulation of labour between firms, clear evidence of this has not been forthcoming (Dayasindhu, 2002; Lema and Hesbjerg, 2003).

The final characteristic has been collaboration: the ability of software firms to work together in areas of mutual benefit such as policy advocacy, overseas marketing, market research, and distribution of best practice (ibid.). This has typically been enabled by the software industry associations and effective government agencies found in all three countries: Nasscom and the Department of IT in India; the Irish Software Association and the National Software Directorate in Ireland; and the Israeli Association of Software Houses and the Office of the Chief Scientist in Israel. What one finds much less of is inter-firm commercial collaboration, with the extent of local backward/supplier and forward/client linkages being particularly limited in India (Arora et al., 2001b) and, to a lesser degree, Ireland (Grimes, 2003). In all cases, though, international linkages seem to have been far more significant than local ones in terms of supply of both formal inputs such as technology and finance and informal inputs such as information and knowledge. It is to these supply factors that we now turn.

\section{Supply Factors and Infrastructure}

Many factors form the tapestry of domestic infrastructure that supports and enables software exports. The 3Is have strengths in relation to a number of these factors that have helped contribute to their export success.

\section{People}

In reviewing the evidence summarised in Appendix 1, we find all but one of the sources citing labour inputs as a contributing factor to the software export successes 
of the 3I nations. It is the most-cited single contributing factor, typically described in terms of the size and skills/expertise of the indigenous labour pool. In part, this may be pre-existing: India and Israel have had strong scientific and technical establishments (including those related to defence) since the 1950s. In part, though, labour has been developed through deliberate government intervention to build the IT skills base, especially at tertiary level, where all three have had and have strengthened excellent technical education institutions (Carmel, 2002). The result, for example, is higher numbers of scientists, engineers and technicians per head of population than in neighbouring countries (UNDP, 2003).

As well as labour supply, labour demand has also been important. Talent has been attracted into software exports in the 3Is because of the stability, prestige, money and other rewards this segment offers (Tessler et al., 2003) and, by contrast, because of the fewer or weaker rewards and opportunities offered to labour in other sectors, including domestic-oriented software work (Arora and Gambardella, 2004).

Labour costs are cited by Western client/investor interviewees as an important element in their decisions to source software from follower nations. These nations have a clear advantage over, say, the US where average annual programming wages are more than US\$50,000 per year (BLS, 2003). By contrast, figures for Ireland and Israel are in the mid-US\$20,000s, and figures for India are somewhere between US\$5,000 and US\$10,000 (Nasscom, 2003; Kublanov and Satyaprasad, 2004).

Overall, though, the labour cost issue must be kept in perspective and set alongside, rather than necessarily above, other factors. Whatever the output - services or products, onsite or offshore - 3I labour costs make up only a minority of total production costs (Heeks, 1996; neoIT, 2004). In addition, interview and other evidence (Robb, 2000; Grimes, 2003) shows clients/investors rate labour skills and motivation, and the ability to close their labour demand - supply gap as more important than costs. In Ireland, therefore, there has been continued software export growth despite labour costs that exceed those of several other European countries, and software products from Israel and other 3Is have competed on the basis of quality and fit to needs rather than on price. 
Two other people-related elements figure in the 3Is' success. English, the global business and IT language, dominates higher education and, to a significant degree, business in all the 3Is. The second element is knowledge. Initially through the diaspora but later through exports and client linkages, staff in 3I software exporters have built up a strong knowledge base: about overseas software markets, about overseas business norms and practices, and about specific customer needs and values (Kapur and McHale, 2002; Lema and Hesbjerg, 2003). This has put them in a strong position to sustainably grow their software export business, whether in services or products.

\section{Technology}

Both Ireland and Israel have benefited from a strong technological infrastructure - of both hardware/software and digital telecommunications - that (at least in cluster locations) is equivalent to client country norms (Coe, 1999; Reddy, 2001). This can be attributed to liberalisation combined with government and foreign investment (Grimes, 2003; KPMG/Nasscom, 2004).

In its early years, India's domestic technological base was a critical weakness, not success factor. Hence, in part, the reliance on bodyshopping as a way of shortcircuiting that weakness. Since 1991, government investments have grown and liberalisation has increased the involvement of private funds and foreign investments in the technological infrastructure. Barriers to such investments, including import tariff barriers, have also been reduced. As a result, we find from our field research that the penetration and currency of computer hardware and telecommunications infrastructure in software cluster locations now approaches that found in some Western countries.

\section{Finance}

Governments in all three countries have acted to stimulate the supply of working and venture capital to software firms. All three have used a raft of tax breaks, marketing subsidies, grants, loans, legislative updates and removal of red tape in an effort to achieve this: a combination of both liberalisation (less government) and promotional 
intervention (more government) (Tessler et al., 2003). The Israeli government, for example, set up the "Yozma" scheme in 1992 as a way to try to encourage and channel flows of venture capital funds from overseas (Teubal, 2001). The government itself was able to withdraw from direct intervention in 1997 but its US $\$ 100 \mathrm{~m}$ of pump-priming created a self-sustaining venture capital industry that has invested US\$ billions in Israeli high-tech, including hundreds of software start-ups.

All three countries have also benefited from heavy investments of overseas aid that has been channelled into infrastructural investments. This has come from the international donor community in India's case; via the European Union for Ireland; and from the US for Israel.

\section{Research and Development $(R \& D)$}

India, Ireland and Israel have all experienced support for investments in softwarerelated research and development, directly via government funding and indirectly via tax breaks for private sector R\&D. In all cases, this has brought at least some indirect benefit for the human infrastructure; building skills and knowledge (Tessler and Barr, 1997). The innovation benefits have varied. In product-focused Israel, with the highest R\&D investments of the three, they have been crucial (Teubal et al., 2000; Khavul, 2003). Government-subsidised multimedia projects have been spun off into games and business and home applications. Military-funded developments in signal processing and encryption have emerged in a variety of Internet communication and security packages. In service-focused India, though, we found success stories especially commercialisation of publicly-funded R\&D - to be few and far between.

\section{Other}

Governments in the 3I nations have helped by providing or enabling an infrastructure of transportation (road and air), utilities, and business accommodation, especially to software export cluster locations. They have assisted the knowledge infrastructure of ideas and best practices in their support for process/quality certification and for software industry associations. They have also provided the legal "infrastructure" that enables reliable contracting and product development. 


\section{The Software Export Success Model}

A summary of the analysis above is presented in Table IV, listing those factors which have been seen to contribute to the success of software exports in each of the 3I nations.

TABLE IV First-Tier Country Success Factor Similarities and Differences.

\begin{tabular}{|c|c|c|c|}
\hline & India & Ireland & Israel \\
\hline Demand & $\begin{array}{l}\text { High external } \\
\text { demand; weak } \\
\text { domestic demand }\end{array}$ & $\begin{array}{l}\text { High external demand; } \\
\text { small domestic } \\
\text { demand }\end{array}$ & $\begin{array}{l}\text { High external demand; } \\
\text { small domestic } \\
\text { demand }\end{array}$ \\
\hline $\begin{array}{l}\text { National Vision } \\
\text { and Strategy }\end{array}$ & $\begin{array}{l}\text { Vision and strategy } \\
\text { present: onsite } \\
\text { software services, } \\
\text { then offshore } \\
\text { management; } \\
\text { relevant institutions }\end{array}$ & $\begin{array}{l}\text { Vision and strategy } \\
\text { present: product- } \\
\text { related services for } \\
\text { multinationals, then } \\
\text { embedding; relevant } \\
\text { institutions }\end{array}$ & $\begin{array}{l}\text { Vision and strategy } \\
\text { present: home-grown } \\
\text { product exports, then } \\
\text { innovation and } \\
\text { differentiation; } \\
\text { relevant institutions }\end{array}$ \\
\hline $\begin{array}{l}\text { International } \\
\text { Linkages }\end{array}$ & $\begin{array}{l}\text { Diaspora and created } \\
\text { links, especially with } \\
\text { MNCs; reputation } \\
\text { and trust, partly } \\
\text { through CMM/ISO } \\
\text { and anti-piracy }\end{array}$ & $\begin{array}{l}\text { Diaspora and created } \\
\text { links, especially with } \\
\text { MNCs; reputation and } \\
\text { trust, partly through } \\
\text { ISO/CMM and anti- } \\
\text { piracy }\end{array}$ & $\begin{array}{l}\text { Diaspora and created } \\
\text { links, especially with } \\
\text { MNCs; reputation and } \\
\text { trust, partly through } \\
\text { government support }\end{array}$ \\
\hline $\begin{array}{l}\text { Software } \\
\text { Industry } \\
\text { Characteristics }\end{array}$ & $\begin{array}{l}\text { Some large firms; } \\
\text { some effects from } \\
\text { competition, } \\
\text { clustering and } \\
\text { collaboration }\end{array}$ & $\begin{array}{l}\text { Some large firms; } \\
\text { some effects from } \\
\text { competition, clustering } \\
\text { and collaboration }\end{array}$ & $\begin{array}{l}\text { Some large firms; } \\
\text { strong competition; } \\
\text { some effects from } \\
\text { clustering and } \\
\text { collaboration }\end{array}$ \\
\hline
\end{tabular}




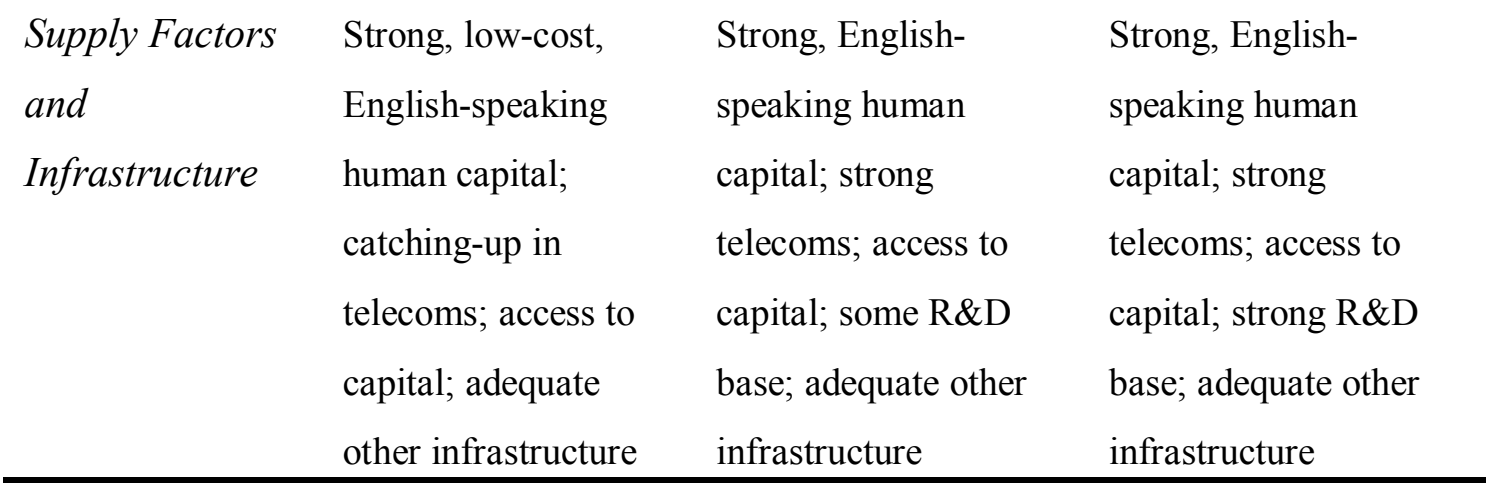

On the basis of this analysis, the five-factor list given earlier can now be presented graphically in greater detail. It is shown in Figure 1 as the "Software Export Success Model". It shows drivers at top (pull/demand drivers) and bottom (push/supply drivers), and enablers in the middle. Factors that emerged with some qualification are shown in italics.

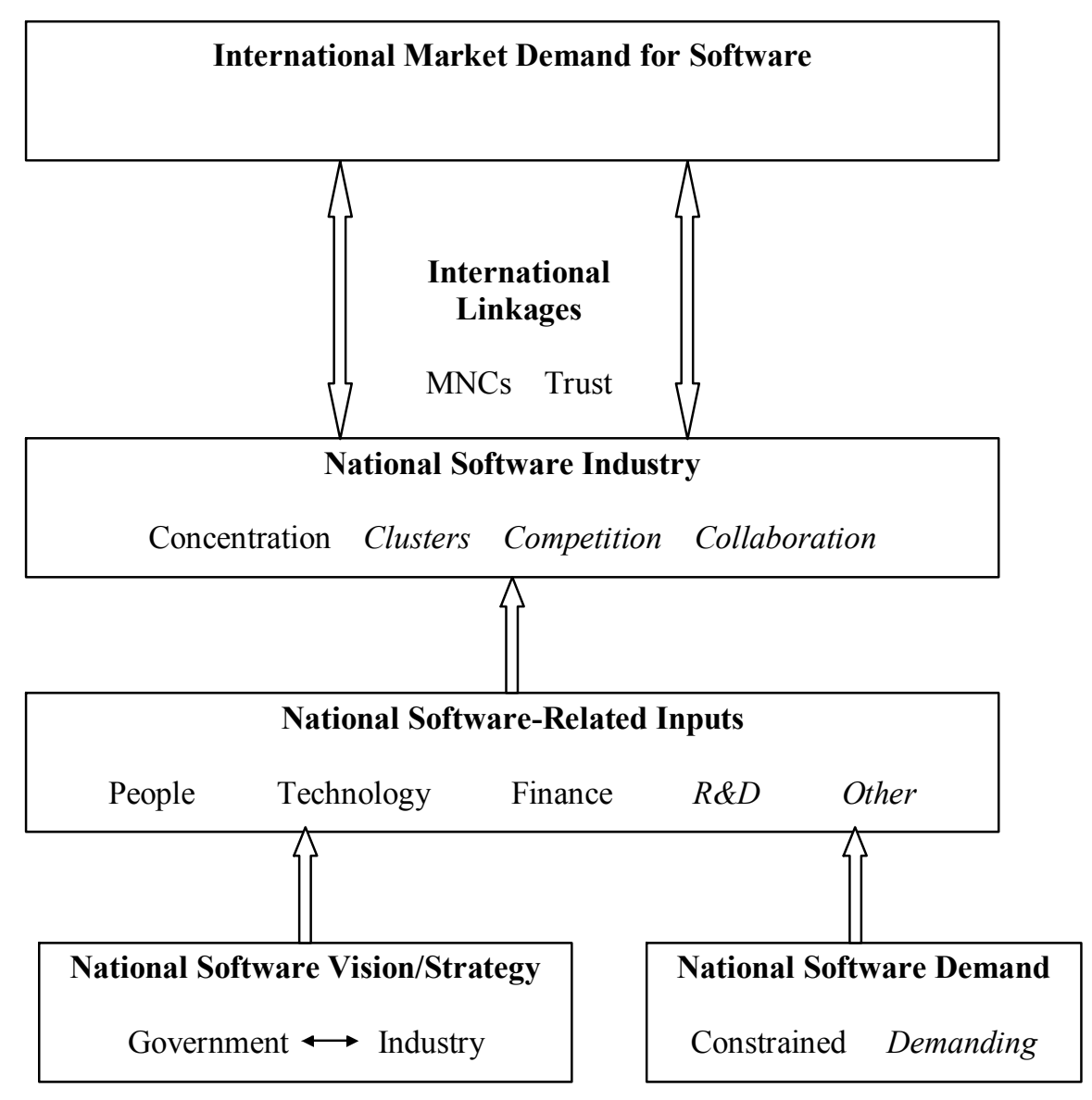

FIGURE 1 The Software Export Success Model. 
The model has been developed from professed and/or demonstrated causal links derived through qualitative rather than quantitative analysis. Thus, for example, it is not possible to offer a weighting of factors in terms of their contribution to the successful export outcomes observed in the 3Is. Nor is this a controlled experiment in which one could test whether success could still be achieved in the absence of particular factors.

Nonetheless, we find the consistency of presence of factors across India, Ireland and Israel to be striking. One "storyline" presented for the 3Is is that of difference in terms of both causation and profile (e.g. Gallen, 2001). In analysing the bases for software export development, though, we find many threads of commonality. ${ }^{11}$ Key elements summarised in Table IV and Figure 1 - constrained local demand; diasporaand MNC-related international linkages; first-mover reputation advantages; the presence of large firms, clusters and supportive government and business institutions; the strong labour pool and enabled access to other inputs; government action to prioritise and support the sector; and other factors - appear in all three. Evidence to date therefore suggests that these are important contributing factors to software success. Given this, we can use the model as the basis for a comparative analysis of strengths and weaknesses of other follower nations.

\section{ASSESSING SECOND-TIER SOFTWARE EXPORT FOLLOWERS}

Having developed a categorised factor model of software export success from the experiences of the leading players, we can now move to make use of it as a comparative tool, assessing the performance and potential of other follower nations.

\footnotetext{
${ }^{11}$ One might also wish to question the differentiation of the 3Is' profile into the stereotypical association of India with programming services, Ireland with package localisation, and Israel with niche products. Software package exports form only a small proportion of the Indian total but still grew from roughly US\$10m in 1993/4 to nearly US\$250m in 2003/4 (Heeks, 1996; Ahmad, 2004). Investments in software R\&D centres in India are also growing. Conversely, foreign investments in Israel have meant that much of its software work is actually equivalent to outsourced R\&D services that are incorporated into foreignowned packages (Teubal, 2001). Finally, strip out the transfer pricing from Ireland's export figures and one sees in 2004 a much more diverse industrial profile that mixes elements of all three stereotypes. It is beyond our scope here to analyse this further but the evidence to date contains at least some hints of convergence.
} 
We focus here on what can be termed the "second tier" of followers; defined as those which make an export contribution of at least $0.05 \%$ of the global market (i.e. onetenth of the criterion for first-tier followers; equivalent to roughly US\$200m in 2003) but not more than the $0.5 \%$ achieved by the first-tier nations.

This category includes nations such as Finland and New Zealand (see e.g. Watson and Myers, 2001; MED, 2003) but our particular interest was to look at second-tier followers among the developing and transitional economies of the world because of the developmental benefits (noted earlier) that a software export industry can bring to such countries. Given this narrowing of scope, only two countries - Russia and China - fell into the second-tier category. Some key indicators for these nations are provided in Tables V and VI. In addition to the size of their software exports, they also show other differences to the first-tier nations:

- Longevity and maintenance: these particular second-tier followers only began significant software exports in the mid-late 1990 s, some years later than the firsttier nations; partly as a result, they have not maintained their market share for so long.

- National significance: software exports in these two nations are not even one-tenth as significant a contributor to GDP and to overall exports as they are in the firsttier nations.

TABLE V Software Exports from Developing/Transitional Second-Tier Followers.

\begin{tabular}{ccc}
\hline & Russia $^{12}$ & China $^{13}$ \\
\hline 2003 & 475 or 350 or 330 or 300 & 2000 \\
2002 & 350 or 300 or 256 & 1500 \\
2001 & 210 or 194 or 175 or 154 & 720 \\
2000 & 126 or 100 or 60 & 400 \\
1999 & & 250 \\
1998 & & 130 \\
\hline
\end{tabular}

\footnotetext{
${ }^{12}$ Statistics are notoriously hard to gather in Russia - a legacy of state manipulation and mistrust - and analysis suffers from the lack of a single definitive source for software industry data. Italicised figures are those which are closest to the average of all the estimates provided, and it is these which are used in any future calculations.

${ }^{13}$ These figures include "exports" to Hong Kong which, despite its special status, is still legally part of the People's Republic of China. In addition to the debatability of including such data, it is unclear if any transfer pricing goes on between firms based in Hong Kong and the rest of China.
} 
Source: Russia (Terekhov, 2001; DoC, 2002; Kozlov, 2002; Ernst \& Young, 2003; Market-

Visio/Gartner, 2003; Kublanov and Satyaprasad, 2004; Rumyantseva, 2004; Hawk and McHenry, forthcoming); China (Economic Daily, 2002; Cao, 2004; Wenlei, 2004).

TABLE VI Other Software Indicators for Developing/Transitional Second-Tier Followers.

\begin{tabular}{lcc}
\hline & Russia & China \\
\hline Software exports as \% of GDP & $0.081 \%$ & $0.14 \%$ \\
$(2003)$ & & \\
Software exports as \% of goods \& & $0.23 \%$ & $0.42 \%$ \\
services exports (2003) & & \\
Domestic-oriented revenue ${ }^{14}$ & US\$1.25bn & US\$9.58bn \\
Total software revenue & US\$1.55bn & US\$11.58bn \\
Export proportion of total revenue & $19 \%$ & $17 \%$ \\
\hline
\end{tabular}

Source: World Bank world development indicators; World Trade Organisation world trade indicators, Rumyantseva (2004), Xi (2004).

We will now use the export success model to investigate why the second-tier nations have been less successful software exporters than the first-tier nations by analysing the strengths and weaknesses of Russia and China vis-à-vis the model's categories and factors. Some elements of the model - specifically the presence of strong international demand - can be taken as a given for all countries. Most elements, though, need to be analysed on a country-by-country basis.

\section{Russia}

Tables V and VI provide a basic, albeit rather uncertain, understanding of the Russian software industry including its strong domestic-market orientation. Of total software exports, some $15 \%$ came from products, which tend to be individual applications with

\footnotetext{
${ }^{14}$ Figures for Russia are for 2002; figures for China are for 2003.
} 
a strong scientific or technical content - such as text recognition, anti-virus or gamesrelated applications - rather than clusters of products within a niche (Ernst \& Young, 2003). The remainder of exports are software services, typically offshore programming work.

Best estimates are that some 70,000 software professionals work in the industry, of whom around 15,000 are focused on exports (Hawk and McHenry, forthcoming). One can estimate that up to 300 firms worked on software exports, with three types taking roughly equal shares of the export market: larger commercial firms, smaller companies or groups who operate in a relatively informal way (there are more than two hundred of these), and a small number of overseas development centres that are partly or wholly foreign-owned such as subsidiaries of Motorola, Intel, Sun and Microsoft (Kitov, 2001; Market-Visio/Gartner, 2003).

We analysed the Russian software industry on the basis of the export success model using interview and secondary source data. Although the model draws together the experiences of all three first-tier nations, the emphasis of some secondary sources has particularly been a comparison with India because of the dominance of offshore programming work in Russia exports, a characteristic it shares with India. Details of our source analysis is presented as Appendix 2. Here we present an overview of comparative strengths and weaknesses.

One immediate point that was notable from our interview data and that is reflected in Appendix 2 is the way that the industry has changed in a relatively short period of time. In the mid-late 1990s, exports were small and there was a dominant sense of shortcomings and weaknesses. By 2004, the strengths of the industry were more apparent and some weaknesses had been - or were being - addressed.

The main strength of the Russian industry lies in its human capital. Technical education has been a considerable strength for many years with Russia ranking third in the world in terms of per capita scientists and engineers (UNDP, 2003). Significant numbers of these have had experience in major nuclear, space, military and communications projects and have moved into the software industry (Terekhov, 2001). 
Understanding whether labour costs are also an advantage has been difficult because of the variety of figures initially in circulation. Recent estimates suggest that a clear distinction needs to be made between costs in Moscow and St. Petersburg, and costs in the Russian regions (Hawk and McHenry, forthcoming). Figures from Ernst \& Young (2003) suggest that annual salary costs for a software programmer based in the regions are around US\$6,000; roughly at par with average costs in India. Costs for a Moscow-based programmer are more like US\$10,000. Russian firms therefore enjoy a considerable cost advantage over US or even Irish and Israeli competitors, but typically some small disadvantage compared to India.

A second strength has been proximity to European markets; a strength that has been interpreted not just in geographic but also cultural terms (Valimaki, 2004). As discussed later, this is a strength that Russian software firms are only just beginning to make use of.

Other aspects of the Russian software industry represent factors that are helpful contributors to software export success but in which Russia has no particular advantage compared to the first movers. One example is clustering of software firms which has occurred in Moscow, St. Petersburg and Novosibirsk, coalescing around the local state universities and featuring local marketing consortia (Sahay et al., 2003). This has brought the expected benefits seen in the 3Is so that, for instance, while telecommunications infrastructure is weak on a nationwide basis, it is up to global standards within the clusters.

Alongside this, though, there are identifiable model factors in which the Russian software industry is weak compared to the first-mover nations. These are identified in Appendix 2 and we will just highlight three factors here that have been particularly noticeable from the interviewed consortium representative and other sources. The first is the lack of any clear vision or strategy for software export growth in the country (e.g. Kublanov and Satyaprasad, 2004). Firms have been left largely to their own devices, with few of the supportive interventions found, for instance, in the 3Is. This has had a particular knock-on into input weaknesses: limited financing, limited 
marketing and management expertise, and the extra-cluster telecommunications limitations just noted are all the result.

Given the many economic, political and social pressures that Russia has faced during its transition, plus the limited size of software exports, the lack of government focus is not particularly surprising. However, it has been exacerbated by the industry's inability to develop a single, authoritative organisation that could lobby for changes. Instead, there are at least eight associations with software firm membership (Hawk and McHenry, forthcoming), with relations further problematised by the transitionalnation mindset of new entrepreneurs who are more likely to regard government as an enemy rather than a partner.

These weaknesses, in turn, feed into a third factoral drawback: the poor overseas image of Russia that can undermine attempts to develop international linkages (ACCR, 2001). Individual firms have made progress in this field: their clientdeveloper relationships are deepening and, after a delayed start, the main firms are undergoing ISO or CMMI certification (WITSA, 2004). However, they find themselves facing an uphill struggle because of the picture potential clients/investors have of Russia. It is seen, rightly, as suffering from very high levels of software piracy: around $87 \%$ compared to a world average of $40 \%$ (Lakaeva, 2004). Perceptions of a weak legal system, widespread corruption, fragile democracy and heavy-handed bureaucracy have all restricted the development of trust and, hence, the development of both exports and international linkages.

Finally, there is the issue of domestic demand. Although not an overall sectoral weakness, the strength and nature of demand for software within Russia itself does interfere with prospects for software exports. This is particularly so because of the barriers to export that entrepreneurs face. Compared, say, to the situation facing a new entrant in India, Russian software entrepreneurs find they have to work harder to gain market information, to make contacts, to overcome trust and reputation barriers, and they have to do all this with fewer opportunities for assistance from external organisations. The comparative incentives to focus on the domestic market are therefore much greater, though this only serves to reinforce the relative lack of understanding of Western clients and Western business practices. 


\section{China}

China's software industry shares much in common with its Russian counterpart; its larger size nearly proportionate to its greater population as shown in Tables V and VI, where revenues are six-seven times larger, but domestic market dominance and contributions to GDP and exports are of a similar order. As ever, estimates vary but there are thought to be about 6,000 software firms in China employing perhaps 300,000 people (Economic Daily, 2002; Cao, 2004). Figures on the balance between services and products in exports are hard to find but one estimate suggests at least three-quarters (and possibly more) of exports are services (KPMG/Nasscom, 2004).

The most significant aspect to China's software export profile is that exports are almost entirely regional. Around half of all software exports go to Japan, a significant proportion of the rest go to Hong Kong, and virtually all the rest go to South Korea or to South-East Asia, including Singapore (IDC, 2003; Wenlei, 2004). Even ignoring the questionable inclusion of Hong Kong as an export location, the great bulk of China's software exports go to places with which it has linguistic commonalities.

Appendix 3 presents a source analysis of China's strengths and weaknesses according to the software export success model. Two supply input factors - labour costs and technological infrastructure - are argued as comparative strengths in relation to India (usually taken as China's main benchmark). In practice, though, the actual impact of these strengths seems limited. Labour cost differences to India are not great - perhaps $80-90 \%$ of equivalent Indian costs ${ }^{15}$ - and much of that will be eroded by non-labour costs of outsourcing. IT diffusion rates are certainly greater with, for example, per capita Internet penetration rates being more than five times higher in China than in India (Sviokla, 2003). But this average figure masks much more limited inter-country differences when comparing the main urban locations in which software exporters are located. Instead, China's particular software export strengths appear to be the lessdiscussed factors of its regional location and links, and its Chinese language skills.

\footnotetext{
${ }^{15}$ For example, Ernst \& Young (2003) cite average annual programmer costs in China of US $\$ 4,750$ as compared to US $\$ 5,850$ in India.
} 
A number of factors have potentially contradictory effects. For instance, some commentators have seen the strength of domestic demand in China as a good thing for exports: a base from which to build (Economic Daily, 2002). In practice, though, the stronger impact seems to have been as in Russia to divert firms away from exports: data from 2001 shows that, of China's top twenty software firms by overall revenue, thirteen had no exports and only two exported more than US\$10m-worth of software (Qu and Brocklehurst, 2003). They therefore lack knowledge of overseas markets and retain China-specific working practices and organisational cultures that are seen to clash with those of Western organisations (Valimaki, 2004).

There has been a clear government strategy (perhaps even a vision) for software in China for some time ( $\mathrm{Li}$ and Gao, 2003). The first policies for software sector development emerged in China in the 1980s; prioritisation of software, including software exports, was enshrined within the tenth five-year plan (2001-2005); and there were significant software policies in 2000 ("Notice of Certain Policies to Promote the Software and Integrated Circuit Industry Development") and 2002 ("Program of Action for Invigorating the Software Industry") (Kharbanda and Suman, 2002; Cao, 2004). Such policies have announced some general actions such as expansion of IT education and development of more technology parks. They have also brought specific benefits for software exporters such as lower export credit rates and import/earnings tax allowances, access to cheap capital, and relaxation of rules on both sending employees abroad and going public. On the other hand, strong government investment in the domestic market has caused indirect difficulties for exports, as has government's contribution to the package of factors that undermine linkages and trust: perceived corruption, an autocratic and bureaucratic style overlaying personal connections, high levels of software piracy, and the currently heavilyrepressed potential for major political instability (Gong, 2002; Saxenian, 2003).

In theory, China's diaspora should be a source of strength, given the key role played by the diaspora in the 3Is. China's diaspora is much larger than that of India, for instance: there are 50 million overseas Chinese compared to 15-20 million Indians, and their foreign direct investment into China has been twenty times that of nonresident Indians to India (Kapur and Ramamurti, 2001). However, overseas Chinese are far less globally-dispersed than the Indian populations, being concentrated in 
Hong Kong, Taiwan and South-East Asia, thus reinforcing a regional focus. In addition, they are mainly manufacturers and traders who tend to invest in manufacturing, whereas overseas Indians - being mainly managers and professionals - have tended to invest more in knowledge-intensive services like software (ibid.). ${ }^{16}$

As in Russia, there are factors that can be regarded as neutral: they appear necessary to software exports but offer no particular advantage to this second mover. An example would be the clustering of software firms (Sahay et al., 2003). Zhongguancun science and technology park in Beijing is a key cluster; home to IBM and Microsoft subsidiaries as well as dozens of other software firms. There are clusters in a number of coastal areas, such as Shanghai and Dalian. China's other cluster strength is in Hong Kong and its associated regions, with nearby mainland cities of Shenzhen and Guangzhou hosting a growing number of satellite offices for Hong Kong software firms.

Lastly, though, there are areas in which China has a comparative weakness that undermines its abilities to export software, at least as seen from the perspective of the 3Is' experience. Issues that may undermine reputation, trust and, hence, the formation of international linkages have been noted above. They are not helped by the limited number of process quality certifications undertaken: for example, China had just two CMM level 5 firms at a time when India had 60 (DoC, 2004). In part this reflects China's later awareness of the importance of certification but it is also indicative of China's actual shortcomings in management expertise. It is also short of Englishlanguage expertise, a simple but fundamental competency for those nations wishing to compete in the global software market.

\footnotetext{
${ }^{16}$ An open question remains in relation to US links. Silicon Valley's China-born population is second only to India-born (Kapur and McHale, 2002); there are said to be more Chinese-origin heads of high-tech firms in Silicon Valley than India-born heads (Kharbanda and Suman, 2002); and Saxenian (2002) reports higher return migration rates among Chinese than Indians. In theory, this should be fertile ground for the development of software exports to the US market but, in practice, it does not seem to have materialised to any major degree.
} 


\section{TRAJECTORIES AND STRATEGIES FOR SECOND-TIER FOLLOWERS}

Despite their differences, analysis using the software export success model shows that Russia and China seem to have much in common. In both, the attractive nature of domestic demand combines with a set of constraints to exports: shortcomings in government interventions; lack of trust among potential Western clients and lack of knowledge and relevant contacts among local entrepreneurs; and some competency weaknesses, especially around management, marketing and English. It is the identified constraints which particularly help to explain the relatively late entry into software exports and the relatively limited significance of exports to date in the second movers as compared to the first movers. This helps us understand matters to date but we can also use the findings from the model-based analysis to investigate software sector trajectories and strategies for both Russia and China.

\section{Strategic Positioning in Software for Second-Tier Followers}

As noted in the introduction, there are two dimensions of software industry focus, related to market served and output type. We can combine these to create a simple picture of possible strategic positions in software that can be taken by firms and/or whole sectors, as shown in Figure 2 (Heeks, 1999b). 


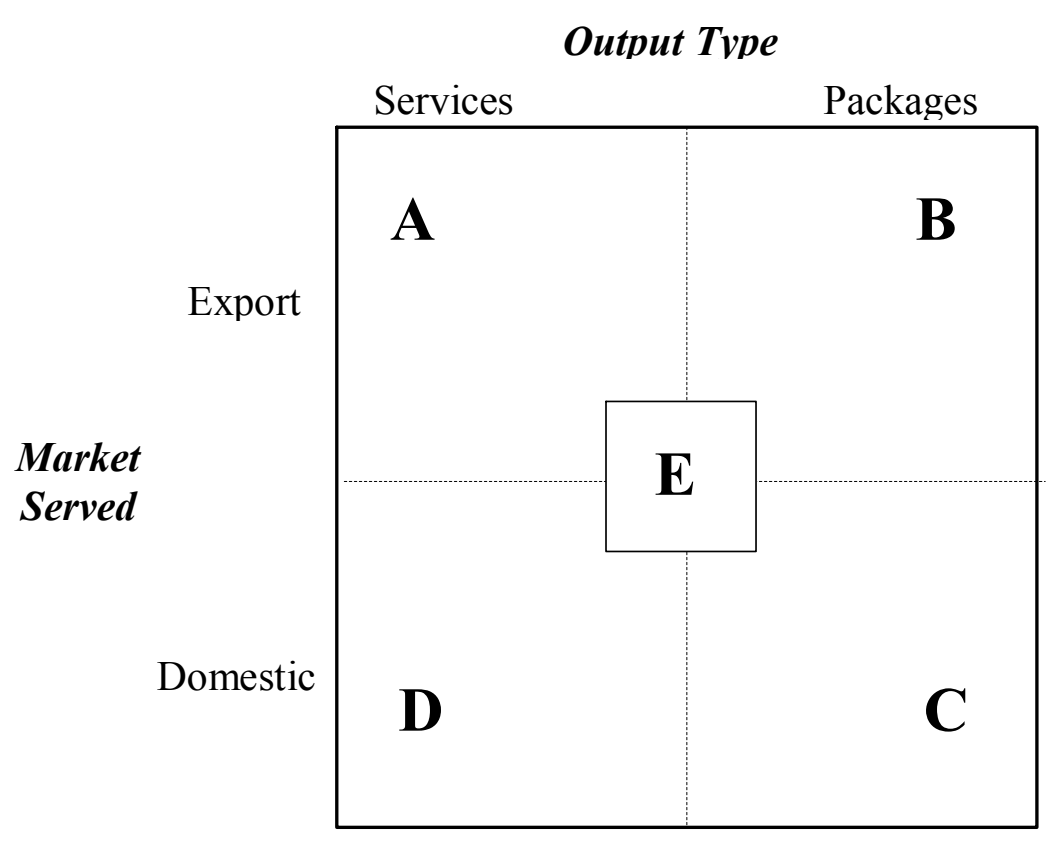

FIGURE 2 Strategic Positioning in Software.

Our earlier analysis shows, for example, that India's software industry is positioned particularly in quadrant A, Israel's in quadrant B, and Ireland's straddling the two given the dominance of product-related service exports. By contrast, the dominant positioning for both second-tier followers has been shown to be quadrant D. How likely is this to change in future, for example to a more export-led development path?

While exports in both countries are likely to grow, a fundamental force we have seen to be shaping these second-tier nations is the relationship between the domestic and overseas markets. Both Russian and Chinese governments are investing US\$ billions in e-government plus other major IT projects like the E-Russia programme or the Beijing Olympics (Lakaeva, 2004; Xi, 2004). Strong growth in the private sector is similarly fuelling the local software market. Most of this e-government and ebusiness investment requires customised software and is not susceptible to piracy. We can then compare this with India, the country whose export profile Russia and China most closely resemble. As a result of the factors noted, plus India's lower GDP per capita, the two second-tier nations have much more attractive domestic markets. They spend around US\$8 per head per year on software, where India spends less than 
$\mathrm{US} \$ 2^{17}$, and software/services is the fastest-growing domestic IT sector, predicted to grow by at least $20 \%$ per year in both countries during the 2000s (Ernst \& Young, 2003; Gems, 2003).

In Russia and China, too, specific local laws, local customs, and local languages mean that foreign software must be localised or that software must be custom-built from scratch. There is something of this in India but the linguistic and other institutional legacies of colonialism mean the domestic market can much more readily be penetrated by "standard" foreign packages. The result, in the two second-tier nations, is first to offer a much greater scope of domestic-oriented activity for local software firms and, second, to make localisation the main priority of multinationals. In a survey of US software firms, for example, localisation of product was listed as the top critical success factor for doing well in the Chinese market (Cao, 2004). In India, with its smaller and more standardised local market, multinationals have scope to think of global outsourcing. In Russia and China, multinationals are more likely to tie up themselves and the local software resources they employ with localisation.

In relation to product-led growth (quadrants B or C), the analysis given above suggests prospects are quite limited. Requirements for customisation and very high package piracy levels in the Russian and Chinese markets have been noted. Hence, for example, less than 5\% of software revenue from the Chinese domestic market derives from packages (Xi, 2004). This weak domestic base removes the kind of foundation for product exports seen in Israel, and the chance of such exports is further damaged by other weaknesses noted in the second-tier followers: their lack of capacity to commercialise state-funded $R \& D$, their lack of Western market knowledge and marketing outlets, and the difficulty of accessing the kind of financing arrangements required to market products overseas.

For those, then, who ask whether these second-tier followers will take an India-type services export-led trajectory (quadrant A) or an Israel-type product export-led trajectory (quadrant B) in future (Kozlov, 2002), the answer on current evidence is "neither". Instead, it seems that a Brazil-type trajectory is more likely in which

\footnotetext{
${ }^{17}$ Calculated by dividing domestic software market size by population size. Actual figures are Russia (US\$8.74 per capita in 2002); China (US\$7.38 in 2003); India (US\$1.88 in 2003/4).
} 
domestic market services (quadrant D) remain the dominant "cake", leaving exports as merely the "icing" (Schware, 1992).

One other position, though, does need to be considered: position "E", which represents a "straddling of the intersections" between the other quadrants. In the case of Russia and China, the main opportunity here is the ability to use demanding, globally-linked domestic customers as a conduit into the global market. As noted above in the analysis of 3I demand, this is a path taken by some firms in all of the 3Is. The extent to which this is currently taking place in the second-tier nations is unclear; certainly in Russia the current crop of firms represented at interview were mainly adopting a "born global" approach that focused directly on exports rather than the "organic" approach of growth through home-based multinationals and subsidiaries. However, given the strong growth of multinational-channelled foreign investment in both countries, plus the increasing tendency of large local manufacturers and service firms to establish global operations, the options for this domestic-to-export growth path are increasing.

\section{Business Strategy for Second-Tier Software Export Followers}

Despite the domestic market bias, there is a wish in Russia and China to expand software exports. To effect this, what business strategies should be adopted? From the business literature (e.g. Porter, 1985), we can identify three main strategies that late entrants may adopt: low-cost, differentiation, and rescoping. We will investigate each of these in turn, using the evidence provided by our software export success model analysis.

As an overall, all follower nations have some element of a low-cost strategy in growing a place in software trade though, as previously discussed, the significance of low cost for the 3Is is rather less than might at first sight be anticipated because of non-labour costs in software development, and because labour costs typically rank below other factors in client ratings. As also seen, the second-tier entrants' cost structures offer little scope for a clear competitive advantage, particularly when firsttier followers can play the same game: late entrants in India sometimes operate by 
trying to undercut going rates, and Indian charges generally are reduced when there are slowdowns in demand (Field, 2001).

Generic differentiation through higher quality or stronger client service also seems a doubtful strategy for late entrants such as the second-tier followers. We have seen that they are latterly playing catch-up but still fall behind India in terms of process quality and the number of overseas offices that could deliver strong client-contact services.

What emerges, then, from our model-based analysis is only one main strategy open to late-entrant followers: focused differentiation - niche market focus in which the late entrants make use of particular strengths that 3I and other competitors lack. Our Russia interview data suggested that there is a clear understanding of the need for this strategy. The Fort-Ross Consortium (a grouping of more than 30 software firms based mainly in St. Petersburg), for example, were focusing on marketing the scientific and technical strengths of Russian programmers. They were combining this with a conscious effort to build up exports in Europe (up to 2003, a majority of Russian software exports were to the US), particularly Scandinavia, in an effort to take advantage of Russia's proximity advantages.

For China, the strategy of focused differentiation in exports means continuing the current trajectory of regional export growth. As we have seen, China lacks the underpinning factors that could build strong growth in Western markets. English and marketing competencies are weak, as are Western links, trust and "brand"/image. China also lacks India's major presence in Western markets - both its onsite programmers and its overseas offices - that has built links, reputation and brand $(\mathrm{Qu}$ and Brocklehurst, 2003). Instead, as described, its unique strengths all relate to regional export markets.

This likely trajectory and strategy has certainly been recognised in India, with Nasscom identifying China as a market and a regional collaborator but not a global competitor ( $\mathrm{Li}$ and Gao, 2003). This is reflected in the investments in China of at least five of India's top ten software exporters (PDO, 2003; Wenlei, 2004). Their Shanghai-based operations are not low-cost centres serving the world market, but 
targeted initially at clients - particularly multinationals - within China, with a longerterm aim of using China as a base to grow their work in the Japanese and Korean markets.

\section{Sectoral Strategy for Second-Tier Software Export Followers}

Whatever strategy the second-tier followers adopt in software exports, they will need to address some of the weaknesses identified by the software export success model analysis. For example, both Russia and China need to strengthen their international linkages. Analysis of actions in the 3Is suggests the following interventions that can be used to help:

- Make it easier for people to get out: reduce the red tape and other restrictions on movement of professionals to other countries.

- Encourage people and money and ideas to come in: this will particularly focus around creating a climate conducive to foreign investment, through tax incentives, liberalisation of financial controls and investment limits, and reduction in other bureaucratic overheads. It will also include stronger contacts with nationals overseas, and the use of workshops, seminars and the like to get ideas into the country.

- Facilitate relationships: investment in both general and specific meetings both incountry and overseas that can help build trade relationships.

- Build trust: address the perceived risks of software exports. Issues like regional instability may be outside institutional control. However, measures that can be taken include new legislation (or at least the appearance of better implementation as in the case of software piracy), and subsidies for CMM/ISO9000 certification.

The two second-tier nations were also found to have weaknesses in their supply inputs and infrastructure that need to be addressed. It is relatively easy to come up with a menu of interventions based on perceived good practices in the 3Is, and a number of authors do this (e.g. Tessler et al., 2003; Sallstrom and Damuth, 2004). Our own summary of interventions, drawn from the sources listed in Appendix 1, is given in Table VII. 
TABLE VII National Interventions to Support Software Export-Related Inputs and Infrastructure.

\begin{tabular}{ll}
\hline Factor & Possible Promotional Interventions \\
\hline People & General education at primary to tertiary levels; Specific further and \\
& higher education and training in IT- and software-related \\
skills/knowledge; Investment/subsidies for research and & development; Encouraging diffusion of best practice \\
Technology & Investment in telecommunications infrastructure; \\
& Encouraging/facilitating greater involvement of private and foreign \\
& investment in telecommunications; Reduction of tariff barriers on \\
& IT imports \\
Finance & Investment in and facilitation of venture and working capital funds; \\
& Encouragement of foreign investment \\
Information & Investment in freely-accessible market research; Subsidised \\
& marketing activities \\
& investment/subsidies for commercialisable research and \\
&
\end{tabular}

In comment and analysis on software exports, there has tended to be a strong emphasis on this type of "menu"-based perspective. To continue the analogy, though, one can take a menu from a Michelin-starred restaurant and give it to the managers of a McDonalds; that does not mean they will be able to produce the required food: they lack the necessary institutional basis and capacities to do so. In the same way, more attention now needs to be given to the institutional arrangements and capacities to deliver effective software sector interventions. 
This has two aspects. First, institutional capacities and their location. A common assumption has been that intervention is something that relates to government and government alone. Yet there is disagreement about the role of the state. Some analysts (e.g. O'Riain, 2000; Teubal, 2001) see the state as a pivotal actor in the development of software exports. Others (e.g. Arora et al., 2001b) see a much smaller role for government and identify ways in which the private sector has been a key actor in the supply-side response to input requirements. It is not easy to resolve the question of the state's role but we are disinclined to downplay it, finding evidence for its importance in: a) the significant resources that interviewed companies were willing to devote to lobbying, b) analysis of causal chains that link state interventions with developmental outcomes in software exports (e.g. UNCTAD, 2002), and c) the appearance of government policy in lists of factors that interviewed clients/investors said shaped their decisions (see also Qu and Brocklehurst, 2003). Analysing the experiences of the 3Is (e.g. Reed and Kelly, 2002; Tessler et al., 2003) certainly suggests for second-tier nations the value of autonomous and capable state agencies with software sector responsibilities, though combined with a strong representative body for the firms in that sector and a mechanism for robust interaction between these two groups.

In addition to these structural considerations, the process of intervention over time is important. Teubal (2001), for example, analyses software policy in Israel and finds a foundation for its positive impact to be the capacity for flexibility, learning and iteration within the institutions of sectoral intervention. Put another way, it may be that the starting content of interventions for second-tier nations is of less importance than imagined; instead, what matters more is the capacity to observe and react to the impacts of interventions and the contextual changes that beset the software export sectors of follower nations.

\section{CONCLUSIONS}

Through analysis of the factors contributing to sectoral growth in the three largest software export "followers", we have built up a new category model, the Software 
Export Success Model. As well as helping to understand the experiences of these first-tier nations, the model has also demonstrated its value as a template to guide a comparative analysis of sectoral strengths and weaknesses in second-tier export followers. This analysis not only helps to explain current software export performance in these countries but it has also provided the foundation for predictive investigation of their software trajectories and prescriptive investigation of their software strategies. This suggests that the two second-tier nations are likely to remain significant niche players rather than directly challenging the more global scope of the 3Is. Even this will depend on the institutional structures and processes that surround strategic interventions aimed at improving software export performance.

Other work with versions of the model (e.g. Bruell, 2003; Gengler, 2003; Nicholson and Sahay, 2003) suggests that its application can readily be expanded beyond the experiences of the five follower nations reported here. The models and related ideas used here can equally be applied to other followers; not just to other second-tier followers like Finland or New Zealand but also to the growing group of "third-tier" followers ${ }^{18}$. This latter group now includes countries like Hungary, Iceland, Indonesia, Mexico, Pakistan, Romania, Ukraine and Vietnam.

In addition to its academic conceptual value, the model can also be used to guide national strategy-making processes for software export. It must be recognised, of course, that the robust analysis of issues provided by the model is only a first step. There must also be a capacity to identify appropriate solutions, to implement those solutions, and to iteratively learn from the cycle of analysis and action.

\section{Acknowledgements}

The authors are very grateful to two anonymous referees for their comments that led to significant revisions of an earlier draft of this paper.

\footnotetext{
${ }^{18}$ Continuing the order of magnitude approach, we can define these as countries which make an export contribution of at least $0.005 \%$ of the global software market (equivalent to roughly US $\$ 20 \mathrm{~m}$ in 2003) but not more than the $0.05 \%$ achieved by second-tier nations. See Carmel (2003a) for an alternative taxonomy.
} 


\section{References}

ACCR (2001) Whitepaper on Offshore Software Development in Russia, American Chamber of Commerce in Russia, Moscow.

Ahmad, I. (2004) Industry overview, Dataquest (India), August. http://www.dqindia.com

Ariav, G. and Goodman, S.E. (1994) Israel: of swords and software plowshares, Communications of the ACM, 37(6), 17-21.

Arora, A., Arunachalam, V.S., Asundi, J. and Fernandes, R. (2001a) The Indian software services industry, Research Policy, 30, 1267-1287.

Arora, A., Gambardella, A. and Torrisi, S. (2001b) In the Footsteps of Silicon Valley? Indian and Irish Software in the International Division of Labour, Working Paper no.2001-12, The Heinz School, Carnegie Mellon University, Pittsburgh, PA.

Arora, A. and Athreye, S. (2002) The software industry and India's economic development, Information Economics and Policy, 14, 253-273.

Arora, A. and Gambardella, A. (2004) The globalization of the software industry; perspectives and opportunities for developed and developing countries, Innovation Policy and the Economy, 5. http://www.nber.org/books/innovation5

Balasubramanyam, V.N. and Balasubramanyam, A. (1997) International trade in services: the case of India's computer software, World Economy, 20(6), 829-843.

Bell, J. (1997) A comparative study of the export problems of small computer software exporters in Finland, Ireland and Norway, International Business Review, 6(6), 585-604.

BLS (2003) U.S. Computer Software Industry, Bureau of Labor Statistics, Washington, DC. http://web.ita.doc.gov

Bruell, N. (2003) Exporting software from Indonesia, Electronic Journal of Information Systems in Developing Countries, 13(7), 1-9.

Cao, S. (2004) Software Industry 2003, Department of Commerce, Washington, DC. http://www.buyusainfo.net

Carmel, E. (2002) Global software outsourcing from developing countries, paper presented at IFIP WG9.4 conference on ICTs and Development, Indian Institute of Management-Bangalore, 29-31 May. 
Carmel, E. (2003a) Taxonomy of new software exporting nations, Electronic Journal of Information Systems in Developing Countries, 13(2), 1-6.

Carmel, E. (2003b) The new software exporting nations: success factors, Electronic Journal of Information Systems in Developing Countries, 13(4), 1-12.

Campbell-Kelly, M. (2003) From Airline Reservations to Sonic the Hedgehog: A History of the Software Industry, MIT Press, Cambridge, MA.

Cochran, R. (2001) Ireland: a software success story, IEEE Software, March/April, 87-89.

Coe, N. (1999) Emulating the Celtic tiger?, Singapore Journal of Tropical Geography, 20(1), 36-55.

Correa, C. (1996) Strategies for software exports from developing countries, World Development, 24(1), 171-182.

Dataquest (2001) The DQ top 20, Dataquest (India), August.

http://www.dqindia.com

Dayasindhu, N. (2002) Embeddedness, knowledge transfer, industry clusters and global competitiveness: a case study of the Indian software industry, Technovation, 22, 551-560.

de Fontenay, C. and Carmel, E. (2003) 'Israel's silicon wadi: the forces behind cluster formation', in: Building High-Tech Clusters, T. Bresnahan and A. Gambardella (eds), Cambridge University Press, Cambridge, UK, 40-77.

DoC (2002) Software Outsourcing Market in Russia, Department of Commerce, Washington, DC. http://web.ita.doc.gov

DoC (2004) ExportITReport India, Department of Commerce, Washington, DC. http://web.ita.doc.gov

Economic Daily (2002) China's software industry vs India's software industry, Economic Daily, 13 June. http://iic.ni.in

EI (1997) ITS 2007: Enterprise Ireland International Services Strategy, Enterprise Ireland, Dublin. http://www.nsd.ie

Ein-Dor, P., Myers, M.D. and Raman, K.S. (1997) Information technology in three small developed countries, Journal of Management Information Systems, 13(4), 61-89.

Ernst \& Young (2003) The Russian IT market, paper presented at $2^{\text {nd }}$ US-Russia IT Roundtable, San Mateo, CA, 20 February.

Field, T. (2001) Hard times, CIO, 20 September. 
Gallen, S. (2001) Background to the Irish Software Industry, National Software Directorate, Dublin. http://www.nsd.ie

Gems, F. (2003) IDC Predictions 2004, IDC, Framingham, MA. http://www.idc.com Gengler, E. (2003) Ukraine and success criteria for the software exports industry, Electronic Journal of Information Systems in Developing Countries, 13(8), 1-18.

Gong, T. (2002) Dangerous collusion: corruption as a collective venture in contemporary China, Communist and Post-Communist Studies, 35, 85-103.

Grimes, S. (2003) Ireland's emerging information economy: recent trends and future prospects, Regional Studies, 37(1), 3-14.

Hawk, S. and McHenry, W. (forthcoming) The maturation of the Russian offshore software industry, Information Technology for Development.

Heeks, R.B. (1996) India's Software Industry, Sage Publications, New Delhi.

Heeks, R.B. (1999a) The uneven profile of Indian software exports, Networks and Communications Studies, 13(1-2), 197-221.

Heeks, R.B. (1999b) Software strategies in developing countries, Communications of the ACM, 42(6), 15-20.

Heeks, R.B., Krishna, S., Nicholson, B. and Sahay, S. (2001) Synching or sinking: global software outsourcing relationships, IEEE Software, March/April, 54-61.

Heeks, R.B. and Nicholson, B. (2002) Software export success factors and strategies in developing and transitional economies, paper presented at IFIP WG9.4 conference on ICTs and Development, Indian Institute of ManagementBangalore, 29-31 May.

Heeks, R.B. and Grundey, M. (2004) Romania's hardware and software industry, in: Information Technology Policy, R. Coopey (ed.), Oxford University Press, Oxford.

IDC (2003) Profiles of China Software Export Companies, IDC, Framingham, MA. http://www.idc.com

IEICI (2004) Israel's Software Industry, Israel Export \& International Cooperation Institute, Tel Aviv, Israel.

Kapur, D. and McHale, J. (2002) Sojourns and Software: Internationally Mobile Human Capital and High-Tech Industry Development in India, Ireland, and Israel, Draft Working Paper. http://www.people.fas.harvard.edu/ dkapur/images/dk_sojourns.pdf 
Kapur, D. and Ramamurti, R. (2001) India's emerging competitive advantage in services, Academy of Management Executive, 15(2), 20-32.

Kelly, L. (2000) Irish eyes smile at software boom, vnunet.com, 17 March. http://www.vnunet.com

Kambhampati, U.S. (2002) The software industry and development: the case of India, Progress in Development Studies, 2(1), 23-45.

Kharbanda, V.P. and Suman, Y. (2002) Chinese initiative in the software industry, Current Science, 83(12), 1450-1455.

Khavul, S. (2003) The Emergence and Evolution of Israel's Software Industry, Centre for New and Emerging Markets, London Business School, London. http://www.london.edu/cnem

King, N. (1998) Template analysis, in: Qualitative Methods and Analysis in Organizational Research, G. Symon and C. Cassell (eds), Sage Publications, London, 118-134.

Kitov, V. (2001) Software firms aim to copy India's success, The Russia Journal, 8 June.

Kodituwakku, D. (2003) The software industry: consolidation, focus and service, Corporate Venturing Journal, November, p2.

Kozlov, V. (2002) Outsourcing in overdrive, The Russia Journal, 25 March.

KPMG/Nasscom (2004) Strengthening the Human Resource Foundation of the Indian IT-enabled Services/IT Industry, Nasscom, New Delhi. http://www.nasscom.org

Krishna, S., Ojha, A.K. and Barrett, M. (2000) Competitive advantage in the software industry: an analysis of the Indian experience, in: Information Technology in Context, C. Avgerou and G. Walsham (eds), Ashgate, Aldershot, UK, 182-197.

Kublanov, E. and Satyaprasad, S. (2004) Mapping Offshore Markets Update 2004, neoIT, San Ramon, CA.

Lai, S.-Y., Heeks, R.B. and Nicholson, B. (2003) Uncertainty and Coordination in Global Software Projects: A UK/India-Centred Case Study, IDPM Development Informatics Working Paper no.17, University of Manchester, UK. http://idpm.man.ac.uk

Lakaeva, I. (2004) Trends in the Russian IT Market, Department of Commerce, Washington, DC. http://www.buyusainfo.net

Lema, R. and Hesbjerg, B. (2003) The Virtual Extension: A Search for Collective Efficiency in the Software Cluster in Bangalore, Roskilde University, Denmark. 
Li, M. and Gao, M. (2003) Strategies for developing China's software industry, Information Technologies and International Development, 1(1), 61-73.

Loane, S. (2003) Exporting small software firms, SEA Software, June, 49-52.

Market-Visio/Gartner (2003) Offshore Software Market in Russia, National Software Development Alliance, Moscow. http://www.nsda.net

McNurlin, B. (2003) Offshore Outsourcing Part I, Sourcing Interests Group, Bell Canyon, CA.

MED (2003) Statistics on Information Technology in New Zealand, Ministry of Economic Development, Wellington. http://www.med.govt.nz

Minton, S. (2003) Untitled, Speen Street Journal, 7 October. http://www.idc.com

Moitra, D. (2001) India's software industry, IEEE Software, January/February, 77-80.

Mowery, D.C. (ed.) (1996) The International Computer Software Industry, Oxford University Press, Oxford, UK.

Nasscom (2003) The IT Industry in India, Nasscom, New Delhi.

http://www.nasscom.org

Nasscom (2004) IT Software and Services Market, Nasscom, New Delhi.

http://www.nasscom.org

Nasscom/McKinsey (1999) The Indian IT Strategy Summit, Nasscom, New Delhi.

http://www.nasscom.org

neoIT (2004) Total Cost of Offshore (TCO), neoIT, San Ramon, CA.

Nicholson, B. and Sahay, S. (2001) The political and cultural implications of the globalisation of software development, Information and Organisation, 11(1), $25-44$.

Nicholson, B. and Sahay, S. (2003) Building Iran's software industry, Electronic Journal of Information Systems in Developing Countries, 13(6), 1-19.

NSD (2004) Software Industry Statistics for 1991-2003, National Software Directorate, Dublin. http://www.nsd.ie

OECD (2000) OECD Information Technology Outlook, OECD, Paris.

Olive, D.A. (2003) Issues relating to IT offshore outsourcing, paper presented at WITSA Public Policy meeting, Hanoi, Vietnam, 26 November. http://www.witsa.org

O'Riain, S. (1997) The birth of a Celtic tiger, Communications of the ACM, 40(3), 1116. 
O'Riain, S. (2000) The flexible developmental state: globalization, information technology and the "Celtic tiger", Politics and Society, 28(2), 157-193.

PDO (2003) Indian IT giant to open software center in China, People's Daily Online, 10 October. http://english.people.com.cn

Porter, M.E. (1985) Competitive Advantage, The Free Press, New York.

Porter, M.E. (1990) The Competitive Advantage of Nations, Macmillan Press, London.

Qu, Z. and Brocklehurst, M. (2003) What will it take for China to become a competitive force in offshore outsourcing?, Journal of Information Technology, 18, 53-67.

Reddy, P (2001) Israel's strength in tech. development, The Hindu, 11 January. http://www.hinduonnet.com

Reed, T.F. and Kelly, D. (2002) The skills gap in the Irish software industry, Irish Journal of Management, 23(2), 95-109.

Robb, D. (2000) Offshore outsourcing nears critical mass, Information Week, 12 June. Rumyantseva, M. (2004) Russian ICT market, paper presented at 2004 WITSA General Assembly meeting, Athens, Greece, 18 May. http://www.witsa.org Sabherwal, R (1999) The role of trust in outsourced IS development projects, Communications of the ACM, 42(2), 80-86.

Sahay, S., Nicholson, B. and Krishna, S. (2003) Global IT Outsourcing: Software Development Across Borders, Cambridge University Press, Cambridge, UK. Sallstrom, L. and Damuth, R. (2004) The Critical Role of the Software Industry in Economic Growth, Computing Technology Industry Association, Oakbrook Terrace, IL.

Saxenian, A. (2002) Local and Global Networks of Immigrant Professionals in Silicon Valley, Public Policy Institute of California, San Francisco, CA. Saxenian, A. (2003) Government and Guanxi: The Chinese Software Industry in Transition, Centre for New and Emerging Markets, London Business School, London. http://www.london.edu/cnem

Schware, R. (1992) Software industry entry strategies for developing countries, World Development, 20(2), 143-164.

SEI (2004) Process Maturity Profile, Software Engineering Institute, Carnegie Mellon University, Pittsburgh, PA.

Sviokla, J. (2003) Harnessing Service Price Deflation, Diamond Cluster, Chicago, IL. 
Terekhov, A.A. (2001) The Russian software industry, IEEE Software, Nov/Dec, 98101.

Tessler, S. and Barr, A. (1997) Software R\&D strategies of developing countries, paper presented at Council on Foreign Relations' Study Group on the Globalization of Industrial R\&D, 9 Jan.

Tessler, S., Barr, A. and Hanna, N. (2003) National software industry development: Considerations for government planners, Electronic Journal of Information Systems in Developing Countries, 13(10), 1-17.

Teubal, M., Avnimelech, G. and Gayego, A. (2000) Globalization and Firm Dynamics in the Israeli Software Industry, Israeli Financing Innovation Schemes for Europe, University of Pavia, Italy. http://ifise.unipv.it

Teubal, M. (2001) Observations on the Indian Software Industry from an Israeli Perspective: A Microeconomic and Policy Analysis, Hebrew University of Jerusalem, Israel.

UNCTAD (2002) Changing Dynamics of Global Computer Software and Services Industry, UNCTAD, New York.

UNDP (2003) Human Development Report, UNDP, New York.

Valimaki, J. (2004) Offshore/Nearshore Outsourcing, Gartner Consulting, Espoo, Finland.

Watson, R. and Myers, M.D. (2001) IT industry success in small countries: the cases of Finland and New Zealand, Journal of Global Information Management, April-June, 4-14.

Wenlei, D. (2004) Hardnosed software battle, Beijing Review. http://www.bjreview.com

Weston, R. (2004) Double standards, Managing Offshore, 1.01, 1-5.

WITSA (2004) Global Sourcing Issues Paper, World IT and Services Alliance, Arlington, VA. http://www.witsa.org

Woods, R.C. (2004) Exporting Software, Sorting Out the Details, Department of Commerce, Washington, DC. http://www.export.gov

Xi, X. (2004) China's IT Market to Continue Strong Growth in the Next Five Years, Department of Commerce, Washington, DC. http://www.buyusainfo.net 


\section{Appendix 1: Categorisation of Factors Underlying 3Is' Software Export Growth}

This Appendix presents the results of content analysis and categorisation of interview and secondary source data that identifies factors underlying software export success in one or more of India, Ireland and Israel. These analyses are conducted from the perspective of the exporting nation but we also include two analyses that draw data from the perspective of Western consumer firms seeking to source software from a follower nation.

\begin{tabular}{|c|c|c|c|c|c|c|}
\hline Data Source & Demand & Vision/Strategy & Global Linkages & $\begin{array}{l}\text { Software } \\
\text { Industry }\end{array}$ & Supply/Infrastructure & $\begin{array}{l}\text { Country } \\
\text { Focus } \\
\end{array}$ \\
\hline Interviews & $\begin{array}{l}\text { Growing global } \\
\text { demand } \\
\text { Weak domestic } \\
\text { market }\end{array}$ & Government policy & $\begin{array}{l}\text { Diaspora } \\
\text { Trust }\end{array}$ & Firm size & $\begin{array}{l}\text { Low costs } \\
\text { Skilled professionals } \\
\text { Access to capital }\end{array}$ & India \\
\hline $\begin{array}{l}\text { Balasubramanyam \& } \\
\text { Balasubramanyam } \\
1997\end{array}$ & & Government policy & Overseas linkages & & $\begin{array}{l}\text { Human capital } \\
\text { Labour costs }\end{array}$ & India \\
\hline Tessler \& Barr 1997 & $\begin{array}{l}\text { Attractive } \\
\text { domestic } \\
\text { market }\end{array}$ & $\begin{array}{l}\text { Government policies on } \\
\text { input factors, IPR and } \\
\text { technology transfer }\end{array}$ & & & $\begin{array}{l}\text { Supply of software talent } \\
\text { English language competence } \\
\text { Financial capital } \\
\text { Entrepreneurship }\end{array}$ & India \\
\hline
\end{tabular}




\begin{tabular}{|c|c|c|c|c|c|c|}
\hline & & & & & Sound telecoms infrastructure & \\
\hline Krishna et al. 2000 & & & $\begin{array}{l}\text { Global } \\
\text { communications }\end{array}$ & $\begin{array}{l}\text { Structure and } \\
\text { management } \\
\text { of firms }\end{array}$ & $\begin{array}{l}\text { Skilled professionals } \\
\text { English language } \\
\text { Access to technology and telecoms }\end{array}$ & India \\
\hline $\begin{array}{l}\text { Kapur \& Ramamurti } \\
2001\end{array}$ & $\begin{array}{l}\text { Large, growing, } \\
\text { sophisticated } \\
\text { market }\end{array}$ & $\begin{array}{l}\text { Government policy on } \\
\text { imports and start-up }\end{array}$ & US-India links & $\begin{array}{l}\text { Strong inter- } \\
\text { firm rivalry }\end{array}$ & $\begin{array}{l}\text { Low-cost, skilled labour pool } \\
\text { English language } \\
\text { Improving telecoms infrastructure }\end{array}$ & India \\
\hline Dayasindhu 2002 & & & $\begin{array}{l}\text { Linkages and trust } \\
\text { Transfers }\end{array}$ & $\begin{array}{l}\text { Industry } \\
\text { clusters }\end{array}$ & Access to inputs & India \\
\hline Kambhampati 2002 & $\begin{array}{l}\text { Rising global } \\
\text { demand }\end{array}$ & & & & $\begin{array}{l}\text { Strong human capital } \\
\text { Access to telecom infrastructure } \\
\text { Time zone placing }\end{array}$ & India \\
\hline Cochran 2001 & & Government policy & $\begin{array}{l}\text { Diaspora } \\
\text { EU membership } \\
\text { Process quality }\end{array}$ & & $\begin{array}{l}\text { Venture capital } \\
\text { Telecoms infrastructure } \\
\text { Well-educated labour force }\end{array}$ & Ireland \\
\hline Reed \& Kelly 2002 & & $\begin{array}{l}\text { Government investment and } \\
\text { tax policy } \\
\text { Partnership between unions, } \\
\text { business and government }\end{array}$ & $\begin{array}{l}\text { Foreign investment } \\
\text { EU membership }\end{array}$ & $\begin{array}{l}\text { Firms in } \\
\text { related areas }\end{array}$ & Skilled, English-speaking labour force & Ireland \\
\hline Ariav \& Goodman & Demanding & & Links to US & & Well-educated professionals & Israel \\
\hline
\end{tabular}




\begin{tabular}{|c|c|c|c|c|c|c|}
\hline 1994 & local market & & & & & \\
\hline Arora et al. $2001 \mathrm{~b}$ & $\begin{array}{l}\text { International } \\
\text { market growth }\end{array}$ & Public policy & $\begin{array}{l}\text { Diaspora } \\
\text { International } \\
\text { linkages } \\
\text { Multinationals }\end{array}$ & $\begin{array}{l}\text { Industry } \\
\text { association } \\
\text { Clustering }\end{array}$ & $\begin{array}{l}\text { Labour supply } \\
\text { English language }\end{array}$ & $\begin{array}{l}\text { Ireland \& } \\
\text { India }\end{array}$ \\
\hline Teubal 2001 & & $\begin{array}{l}\text { Government action on } R \& D \\
\text { and finance }\end{array}$ & $\begin{array}{l}\text { Foreign investment } \\
\text { Links to overseas } \\
\text { markets } \\
\text { Reputation }\end{array}$ & & $\begin{array}{l}\text { Available finance } \\
\text { Skills in large numbers } \\
\text { Reserves of entrepreneurship }\end{array}$ & $\begin{array}{l}\text { Israel \& } \\
\text { India }\end{array}$ \\
\hline Carmel 2003b & & $\begin{array}{l}\text { Government vision and } \\
\text { policy }\end{array}$ & Linkages & $\begin{array}{l}\text { Clusters } \\
\text { Size/number of } \\
\text { firms } \\
\text { Industry } \\
\text { associations } \\
\end{array}$ & $\begin{array}{l}\text { Human capital } \\
\text { Quality of life } \\
\text { Wage costs } \\
\text { Financial capital } \\
\text { Technological infrastructure }\end{array}$ & $\begin{array}{l}\text { 3Is (and } \\
\text { others) }\end{array}$ \\
\hline Arora \& Gambardella & Domestic & & Diaspora & & Human capital & 3Is (and \\
\hline
\end{tabular}




\begin{tabular}{|l|l|l|l|l|l|}
\hline 2004 & demand & & Multinationals & Supply of entrepreneurship \\
\hline McNurlin 2003 & & $\begin{array}{l}\text { Government support } \\
\text { including education and } \\
\text { legal system }\end{array}$ & Process quality & $\begin{array}{l}\text { Size/sophistication of labour pool } \\
\text { Technical infrastructure } \\
\text { Costs } \\
\text { Cultural compatibility }\end{array}$ \\
\hline $\begin{array}{l}\text { Qu \& Brocklehurst } \\
2003\end{array}$ & & Government support & $\begin{array}{l}\text { Trust/reputation } \\
\text { Quality }\end{array}$ & $\begin{array}{l}\text { Labour costs } \\
\text { Competencies } \\
\text { perspective }\end{array}$ \\
\hline
\end{tabular}




\section{Appendix 2: Software Export Success Model-Based Analysis of Data Sources on Russian Software Exports}

Note: items in bold are seen by sources as comparative strengths (particularly in comparison to India); items in italics are seen as comparative weaknesses; items in normal typeface are seen as neutral.

\begin{tabular}{|c|c|c|c|c|c|}
\hline Data Source & Demand & Vision/Strategy & Global Linkages & Software Industry & Supply/Infrastructure \\
\hline Consortium interview & & & $\begin{array}{l}\text { Poor quality/process } \\
\text { control } \\
\text { Poor overseas image }\end{array}$ & $\begin{array}{l}\text { Clustering } \\
\text { Lack of single industry } \\
\text { association }\end{array}$ & $\begin{array}{l}\text { European market proximity } \\
\text { Science/technical skills } \\
\text { Low cost } \\
\text { Lack of English language skills }\end{array}$ \\
\hline Tessler \& Barr 1997 & $\begin{array}{l}\text { Poor domestic } \\
\text { demand due to piracy }\end{array}$ & Lack of government vision & $\begin{array}{l}\text { Poor knowledge of } \\
\text { markets } \\
\text { Image of corruption }\end{array}$ & & $\begin{array}{l}\text { Outdated skills } \\
\text { Lack of English language } \\
\text { Lack of R\&D funds/activity } \\
\text { Poor telecoms infrastructure } \\
\text { Poor venture capital/banking } \\
\text { Lack of entrepreneurial culture }\end{array}$ \\
\hline Terekhov 2001 & & $\begin{array}{l}\text { Little government } \\
\text { focus/support }\end{array}$ & $\begin{array}{l}\text { High piracy } \\
\text { Poor overseas image }\end{array}$ & & $\begin{array}{l}\text { Well-educated technical specialists } \\
\text { Poor infrastructure-legal, financial, } \\
\text { transport, communications }\end{array}$ \\
\hline DoC 2002 & & Poor legislative & & & Telecoms infrastructure in big three \\
\hline
\end{tabular}




\begin{tabular}{|c|c|c|c|c|}
\hline & $\begin{array}{l}\text { infrastructure } \\
\text { Limited government } \\
\text { recognition }\end{array}$ & & & $\begin{array}{l}\text { cluster locations } \\
\text { Poor English language skills } \\
\text { Lack of project management expertise }\end{array}$ \\
\hline Carmel 2003b & & & Clustering & Size/skills of human capital \\
\hline Ernst \& Young 2003 & Government action & Few diaspora links & Industry association & \\
\hline $\begin{array}{l}\text { Market-Visio/Gartner } \\
2003\end{array}$ & & Lack of trust & & Lack of qualified project managers \\
\hline $\begin{array}{l}\text { Kublanov \& } \\
\text { Satyaprasad } 2004\end{array}$ & Government support & $\begin{array}{l}\text { Quality/Process } \\
\text { maturity } \\
\text { Geopolitical } \\
\text { environment }\end{array}$ & & $\begin{array}{l}\text { Cost } \\
\text { Labour pool/education system } \\
\text { Telecoms infrastructure } \\
\text { Cultural compatibility } \\
\text { Time/distance } \\
\text { Language } \\
\end{array}$ \\
\hline Valimaki 2004 & $\begin{array}{l}\text { Government support } \\
\text { IPR security/piracy levels }\end{array}$ & $\begin{array}{l}\text { Political stability } \\
\text { Global reputation }\end{array}$ & $\begin{array}{l}\text { No industry } \\
\text { association }\end{array}$ & $\begin{array}{l}\text { Cultural compatibility } \\
\text { Science/engineering skills } \\
\text { Geographic proximity } \\
\text { Education system } \\
\text { Cost } \\
\text { Language }\end{array}$ \\
\hline
\end{tabular}




\begin{tabular}{|l|l|l|l|l|l|}
\hline & & & & $\begin{array}{l}\text { Labour pool } \\
\text { Marketing skills } \\
\text { Infrastructure }\end{array}$ \\
\hline $\begin{array}{l}\text { Hawk \& McHenry } \\
\text { forthcoming }\end{array}$ & & $\begin{array}{l}\text { Weak government and } \\
\text { educational support }\end{array}$ & $\begin{array}{l}\text { Linkages - } \\
\text { improving } \\
\text { Few quality } \\
\text { certifications }\end{array}$ & $\begin{array}{l}\text { Quality - improving } \\
\text { English language - improving } \\
\text { Fragmented industry } \\
\text { associations }\end{array}$ \\
\hline
\end{tabular}




\section{Appendix 3: Software Export Success Model-Based Analysis of Data Sources on Chinese Software Exports}

Note: items in bold are seen by sources as comparative strengths (particularly in comparison to India); items in italics are seen as comparative weaknesses; items in normal typeface are seen as neutral.

\begin{tabular}{|c|c|c|c|c|c|}
\hline Authors & Demand & Vision/Strategy & Global Linkages & $\begin{array}{l}\text { Software } \\
\text { Industry }\end{array}$ & Supply/Infrastructure \\
\hline $\begin{array}{l}\text { Kapur \& Ramamurti } \\
2001\end{array}$ & & & Nature of diaspora & & \\
\hline $\begin{array}{l}\text { Economic Daily } \\
2002\end{array}$ & $\begin{array}{l}\text { Heavy domestic market } \\
\text { growth }\end{array}$ & $\begin{array}{l}\text { Government does } \\
\text { not understand } \\
\text { specifics of software }\end{array}$ & & & $\begin{array}{l}\text { Poor commercialisation of state } R \& D \\
\text { Poor software management }\end{array}$ \\
\hline $\begin{array}{l}\text { Kharbanda \& } \\
\text { Suman } 2002\end{array}$ & & Government policies & $\begin{array}{l}\text { Chinese diaspora in US IT } \\
\text { sector }\end{array}$ & & \\
\hline Carmel 2003b & & & Weak Western linkages & & $\begin{array}{l}\text { Size/skills of human capital } \\
\text { Language }\end{array}$ \\
\hline Gems 2003 & $\begin{array}{l}\text { Strong growth of domestic } \\
\text { demand }\end{array}$ & & & & \\
\hline Li \& Gao 2003 & $\begin{array}{l}\text { Barriers to penetration of } \\
\text { local market by foreign }\end{array}$ & & $\begin{array}{l}\text { Quality/CMM weaker } \\
\text { Trust weaker }\end{array}$ & & $\begin{array}{l}\text { Costs } \\
\text { Technological infrastructure }\end{array}$ \\
\hline
\end{tabular}




\begin{tabular}{|c|c|c|c|c|c|}
\hline & firms & & & & $\begin{array}{l}\text { English language skills } \\
\text { Weaker project management skills }\end{array}$ \\
\hline $\begin{array}{l}\text { Qu \& Brocklehurst } \\
2003\end{array}$ & Large domestic market & & $\begin{array}{l}\text { Poor process/management } \\
\text { quality } \\
\text { Lack of onsite presence } \\
\text { Limited marketing } \\
\text { Weak diaspora }\end{array}$ & $\begin{array}{l}\text { Industrial } \\
\text { structure }\end{array}$ & $\begin{array}{l}\text { Shortage of qualified labour } \\
\text { Educational and legal infrastructure } \\
\text { English language } \\
\text { Cultural fit }\end{array}$ \\
\hline Sahay et al. 2003 & & & $\begin{array}{l}\text { Focus of diasporan investment } \\
\text { Quality/CMM weaker } \\
\text { Trust weaker }\end{array}$ & $\begin{array}{l}\text { Some } \\
\text { clustering }\end{array}$ & $\begin{array}{l}\text { English language skills } \\
\text { Weaker project management skills }\end{array}$ \\
\hline Cao 2004 & $\begin{array}{l}\text { Requirement of MNCs for } \\
\text { localisation of software } \\
\text { products for domestic } \\
\text { market }\end{array}$ & & High piracy rate & & \\
\hline $\begin{array}{l}\text { Kublanov \& } \\
\text { Satyaprasad } 2004\end{array}$ & & Government support & $\begin{array}{l}\text { Geopolitical environment } \\
\text { Process maturity }\end{array}$ & & $\begin{array}{l}\text { Time/distance } \\
\text { Cost } \\
\text { Education system } \\
\text { Infrastructure } \\
\text { Labour pool } \\
\text { Cultural compatibility }\end{array}$ \\
\hline
\end{tabular}




\begin{tabular}{|l|l|l|l|l|l|}
\hline & & & & Language \\
\hline Valimaki 2004 & & Government support & $\begin{array}{l}\text { Political stability } \\
\text { Piracy/poor IPR } \\
\text { Poor process quality } \\
\text { Poor marketing }\end{array}$ & $\begin{array}{l}\text { Small firm } \\
\text { size }\end{array}$ & $\begin{array}{l}\text { Technological infrastructure } \\
\text { Labour pool costs (than India) } \\
\text { Poor English } \\
\text { Poor marketing skills } \\
\text { Lack of R\&D/innovation } \\
\text { Cultural compatibility }\end{array}$ \\
\hline
\end{tabular}


